\title{
Kinetic bottlenecks to chemical exchange rates for deep-sea animals - Part 2: Carbon Dioxide
}

\author{
A. F. Hofmann ${ }^{1,2}$, E. T. Peltzer ${ }^{1}$, and P. G. Brewer ${ }^{1}$ \\ ${ }^{1}$ Monterey Bay Aquarium Research Institute (MBARI), 7700 Sandholdt Road, Moss Landing, CA 95039-9644, USA \\ ${ }^{2}$ German Aerospace Center (DLR), Institute of Technical Thermodynamics, Pfaffenwaldring 38-40, 70569 Stuttgart, \\ Germany
}

Correspondence to: A. F. Hofmann (andreas.hofmann@dlr.de)

Received: 4 October 2012 - Published in Biogeosciences Discuss.: 9 November 2012

Revised: 5 March 2013 - Accepted: 14 March 2013 - Published: 11 April 2013

\begin{abstract}
Increased ocean acidification from fossil fuel $\mathrm{CO}_{2}$ invasion, from temperature-driven changes in respiration, and from possible leakage from sub-seabed geologic $\mathrm{CO}_{2}$ disposal has aroused concern over the impacts of elevated $\mathrm{CO}_{2}$ concentrations on marine life. Discussion of these impacts has so far focused only on changes in the oceanic bulk fluid properties $\left(\Delta \mathrm{pH}, \Delta\left[\sum \mathrm{CO}_{2}\right]\right.$, etc.) as the critical variable and with a major focus on carbonate shell formation. Here we describe the rate problem for animals that must export $\mathrm{CO}_{2}$ at about the same rate at which $\mathrm{O}_{2}$ is consumed. We analyse the basic properties controlling $\mathrm{CO}_{2}$ export within the diffusive boundary layer around marine animals in an ocean changing in temperature $(T)$ and $\mathrm{CO}_{2}$ concentration in order to compare the challenges posed by $\mathrm{O}_{2}$ uptake under stress with the equivalent problem of $\mathrm{CO}_{2}$ expulsion. The problem is more complex than that for a non-reactive gas, since with $\mathrm{CO}_{2}$ the influence of the seawater carbonate acid-base system needs to be considered. These reactions significantly facilitate $\mathrm{CO}_{2}$ efflux compared to $\mathrm{O}_{2}$ intake at equal temperature, pressure and fluid flow rate under typical oceanic concentrations. The effect of these reactions can be described by an enhancement factor, similar to that widely used for $\mathrm{CO}_{2}$ invasion at the sea surface. While organisms do need to actively regulate flow over their surface to thin the boundary layer to take up enough $\mathrm{O}_{2}$, this seems to be not necessary to facilitate $\mathrm{CO}_{2}$ efflux. Instead, the main impacts of rising oceanic $\mathrm{CO}_{2}$ will most likely be those associated with classical ocean acidification science. Regionally, as with $\mathrm{O}_{2}$, the combination of $T, P$ and $\mathrm{pH} / p \mathrm{CO}_{2}$ creates a zone of maximum $\mathrm{CO}_{2}$ stress at around $1000 \mathrm{~m}$ depth.
\end{abstract}

\section{Introduction}

Modern climate change concerns over ocean chemical impacts arise from two primary issues: metabolic or respiratory stress imposed by rising temperature and the inevitably associated decline in dissolved $\mathrm{O}_{2}$ (e.g. Shaffer et al., 2009), and the impacts of the increase of $\mathrm{CO}_{2}$ content in the oceans.

The primary result of $\mathrm{CO}_{2}$ uptake is ocean acidification, the effects of which on both calcification and the more general systemic metabolic stress is a subject that has been intensely studied in recent years. While the Royal Society (2005) and Caldeira et al. (2005) give an overview over the state-of-the-art of ocean acidification research almost a decade ago, Field et al. (2011) details the newer developments and Brewer (2013) gives an overview over the history of ocean acidification in the 20th century. However, ocean acidification research so far has not yet addressed possible associated respiratory gas exchange limitations for $\mathrm{CO}_{2}$.

In a companion paper (Hofmann et al., 2012), we addressed the problem of changing $T$ and $\mathrm{O}_{2}$ in terms of gas uptake rates across the animal respiratory surface diffusive boundary layer for typical oceanic profiles with depth. Here we describe the related problem for the required $\mathrm{CO}_{2}$ export that must over time match the equivalent $\mathrm{O}_{2}$ import.

The rise in concern over ocean acidification from the invasion of fossil fuel $\mathrm{CO}_{2}$ (e.g. Caldeira and Wickett, 2003, 2005; Royal Society, 2005; Blackford and Gilbert, 2007; Meehl et al., 2007; IPCC, 2007; Zeebe et al., 2008) has lead to increased attention to the potential impact of elevated ocean $\mathrm{CO}_{2}$ levels on marine animals. The early plans for direct ocean $\mathrm{CO}_{2}$ sequestration, first advocated by Marchetti 
(1977), as a means of mitigating the impacts of climate change drew little attention. But as plans for experimental testing of this scheme at a site off Hawaii surfaced opposition soon arose (Haugan, 2003). The first expressions of this from the general public were unspecific and the scientific community soon realised that far too little authoritative information was available (Kita and Ohsumi, 2004). The early laboratory experiments that were carried out showed impacts of elevated $\mathrm{CO}_{2}$ (low $\mathrm{pH}$ ) on calcification in marine species (Gattuso et al., 1998), and potential coralline impacts are today a major field of scientific study (Orr et al., 2005).

The first small-scale experimental field test of true deepsea $\mathrm{CO}_{2}$ injection (Brewer et al., 1999) aroused great interest and was important in resolving numerous complex physicochemical issues such as the role of hydrate formation and the lifetime and fluid dynamics of the material. Images of a deepsea fish swimming within a few centimetres of the released liquid $\mathrm{CO}_{2}$ drew attention and general concerns over possible sub-lethal stress on deep-sea animals quickly became a matter of debate.

Seibel and Walsh $(2001,2003)$ reviewed the existing literature and inferred that impaired physiological performance would occur for many deep-sea animals under elevated $\mathrm{CO}_{2}$ levels and noted in particular that "oxygen transport proteins are highly sensitive to changes in $\mathrm{pH}$." The matter of deepsea $\mathrm{CO}_{2}$ injection was carefully evaluated in a major IPCC report (Caldeira et al., 2005) and the concern that deep-sea animals "would experience serious problems in oxygen supply under conditions of increased $\mathrm{CO}_{2}$ concentrations" was reiterated, but a numerical framework within which to address this was not reported. The possible linkage between $\mathrm{O}_{2}$ and $\mathrm{CO}_{2}$ impacts on the functioning of marine animals remains to be formally addressed. While here we do not address the internal functioning of any animal, we do seek to describe the limits imposed by the chemistry of the oceanic external boundary layer.

The challenge today is to find ways to combine the effects of simultaneous changes in $T, \mathrm{O}_{2}$ and $\mathrm{CO}_{2}$ within the same conceptual and numerical framework so that more quantitative estimates of impacts can be made. The result of long term changes in the ocean's oxygen status under global warming have been studied and modelled extensively (e.g. Zhang et al., 2010; Rabalais et al., 2010; Peña et al., 2010) and, e.g., Shaffer et al. (2009) concluded that the suboxic $\left(\leq 10 \mu \mathrm{mol} \mathrm{O}_{2} \mathrm{~kg}^{-1}\right)$ and hypoxic $\left(\leq 80 \mu \mathrm{mol} \mathrm{O} \mathrm{kg}^{-1}\right)$ oceanic regions would greatly expand. The long-term evolution of the coupled atmospheric and oceanic thermal and $\mathrm{CO}_{2}$ signals under various scenarios has been extensively modelled (e.g. Sarmiento and Toggweiler, 1984; Siegenthaler and Wenk, 1984; Sarmiento et al., 1995; Archer et al., 1998; Archer, 1999; Sabine et al., 2004; Archer, 2005; IPCC, 2007; Archer et al., 2009; Allen et al., 2009; Allison et al., 2009). However, the impact of these combined effects on marine life remains uncertain.
Here we analyse the physical limits that apply, and by the use of simple physical and thermodynamic relationships we shed important light on the differing thermodynamic efficiencies of the mechanisms and routes taken by the $\mathrm{O}_{2}$ and $\mathrm{CO}_{2}$ molecules as they exchange in the boundary between the animal and the bulk fluid. In order to minimise respiratory acidosis and associated detrimental effects (e.g. Perry et al., 2010) as a result of $\mathrm{CO}_{2}$ build-up inside an animal, it is obvious that $\mathrm{CO}_{2}$ must be exported from the cell to keep the respiration reaction energetically favourable and efficient. To maintain mass balance, the rate of $\mathrm{CO}_{2}$ export must be stoichiometrically related to $\mathrm{O}_{2}$ consumption. By analysing the process by which $\mathrm{CO}_{2}$ is transferred from the outer membrane through the diffusive boundary layer to the bulk ocean, it is possible to better evaluate the relative impacts of $\mathrm{O}_{2}$ and $\mathrm{CO}_{2}$ stress and more accurately predict the impacts of climateocean $\mathrm{CO}_{2}$ changes on marine life.

In this paper, we investigate the diffusive limitation of $\mathrm{CO}_{2}$ export as compared to the equivalent diffusive limitation of $\mathrm{O}_{2}$ uptake, which we have reported in a companion paper Hofmann et al. (2012).

It is important to note that we are not addressing here the internal impacts on animal chemical functioning. We simply ask the question of whether, when faced with external $\mathrm{CO}_{2}$ levels that could impair function, the animal must resort to increasing physical flow over the surface, or whether the same boundary layer thickness required for $\mathrm{O}_{2}$ import is still sufficient to support the equivalent, ocean chemistry enhanced, $\mathrm{CO}_{2}$ export.

\section{Materials and methods}

A list of symbols and abbreviations used throughout this paper can be found in Table 1 .

\subsection{The oceanic $\mathrm{CO}_{2}$ removal potential $R P_{\mathrm{CO}_{2}}$}

\subsubsection{Deriving the equations step 1: boundary layer $\mathrm{CO}_{2}$ diffusion with no reaction}

As a first order approximation, the $\mathrm{CO}_{2}$ efflux from an organism that consumes oxygen at a rate of $E^{\mathrm{O}_{2}}$ (in $\mu \mathrm{mol} \mathrm{s}{ }^{-1} \mathrm{~cm}^{-2}$ ) can be defined as follows:

$E^{\mathrm{CO}_{2}}=E^{\mathrm{O}_{2}}$

with the directions of the fluxes being opposite to each other.

We derive our equations by treating diffusion and $\mathrm{CO}_{2}$ reactivity in seawater in two separate steps. First, we assume no $\mathrm{CO}_{2}$ reactivity in seawater, and consider only the hypothetical, purely diffusive $\mathrm{CO}_{2}$ export flux: $E_{\text {diff }}^{\mathrm{CO}_{2}}$. By doing so and comparing final results including both diffusion and reactivity to the hypothetical diffusion-only case, we follow established practice in this field, as Emerson (1975) illustrated the enhanced invasion of $\mathrm{CO}_{2}$ into a lake by comparison to the reaction-free case as well. 
Table 1. List of symbols and abbreviations - listed in the order of their appearance in the manuscript

\begin{tabular}{|c|c|c|c|}
\hline Symbol & Unit & Meaning & Introduced in \\
\hline$\Delta \mathrm{pH}$ & & future changes in the bulk oceanic $\mathrm{pH}$ (ocean acidification) & Abstract \\
\hline$\Delta\left[\sum \mathrm{CO}_{2}\right]$ & $\mu \mathrm{mol} \mathrm{kg}-1$ & future changes in the bulk oceanic dissolved inorganic carbon concentration & Abstract \\
\hline$T-2$ & $\mathrm{~K}$ & bulk oceanic temperature & Abstract \\
\hline$P$ & bar & (hydrostatic) pressure & Abstract \\
\hline$E^{\mathrm{O}_{2}}$ & $\mu \mathrm{mol} \mathrm{s}-1 \mathrm{~cm}^{-2}$ & oxygen consumption rate per area of gas exchange tissue & Sect. 2.1.1 \\
\hline$E^{\mathrm{CO}_{2}}$ & $\mu \mathrm{mol} \mathrm{s}{ }^{-1} \mathrm{~cm}^{-2}$ & carbon dioxide expulsion rate per area of gas exchange tissue & Sect. 2.1.1 \\
\hline$E_{\text {diff }}^{\mathrm{CO}_{2}}$ & $\mu \mathrm{mol} \mathrm{s}{ }^{-1} \mathrm{~cm}^{-2}$ & $\begin{array}{l}\text { hypothetical carbon dioxide expulsion rate per area of gas exchange tissue if } \\
\mathrm{CO}_{2} \text { was not reactive in seawater }\end{array}$ & Sect. 2.1 .1 \\
\hline DBL & & diffusive boundary layer around the gas exchange tissue of an organism & Sect. 2.1.1 \\
\hline$E_{\text {diff, tissue-lim }}^{\mathrm{CO}_{2}}$ & $\mu \mathrm{mol} \mathrm{s}{ }^{-1} \mathrm{~cm}^{-2}$ & $\begin{array}{l}\text { hypothetical diffusion-only carbon dioxide expulsion rate per area of gas ex- } \\
\text { change tissue if only the tissue was to cross, with no DBL around the organism }\end{array}$ & Sect. 2.1 .1 \\
\hline$E_{\text {diff, DBL-lim }}^{\mathrm{CO}_{2}}$ & $\mu \mathrm{mol} \mathrm{s}{ }^{-1} \mathrm{~cm}^{-2}$ & $\begin{array}{l}\text { hypothetical diffusion-only carbon dioxide expulsion rate per area of gas ex- } \\
\text { change tissue if only the DBL was to cross, with no tissue barrier }\end{array}$ & Sect. 2.1.1 \\
\hline$\rho_{\mathrm{SW}}$ & $\mathrm{kg} \mathrm{cm}^{-3}$ & in situ density of seawater & Sect. 2.1.1, Eq. (4) \\
\hline$D^{\mathrm{CO}_{2}}$ & $\mathrm{~cm}^{2} \mathrm{~s}^{-1}$ & molecular diffusion coefficient for $\mathrm{CO}_{2}$ & Sect. 2.1.1, Eq. (4) \\
\hline$L^{\mathrm{CO}_{2}}$ & $\mathrm{~cm}$ & DBL thickness & Sect. 2.1.1, Eq. (4) \\
\hline$\left.\Delta p \mathrm{CO}_{2}\right|_{\mathrm{DBL}}$ & $\mu a t m$ & $\mathrm{CO}_{2}$ partial pressure difference across the DBL & Sect. 2.1.1, Eq. (4) \\
\hline$K 0^{\prime \mathrm{CO}_{2}}$ & 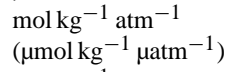 & apparent Henry's constant for $\mathrm{CO}_{2}$ at in situ conditions & $\begin{array}{l}\text { Sect. 2.1.1, defined in } \\
\text { Eq. (5) }\end{array}$ \\
\hline$\left[\mathrm{CO}_{2}\right]$ & $\mathrm{mol} \mathrm{kg}^{-1}$ & $\begin{array}{l}\text { in situ oceanic carbon dioxide concentration. Note that this is the true car- } \\
\text { bon dioxide only concentration, not the total inorganic carbon concentration } \\
{\left[\sum \mathrm{CO}_{2}\right] \text {. }}\end{array}$ & Sect. 2.1.1, Eq. (5) \\
\hline$p \mathrm{CO}_{2}\left(\left[\mathrm{CO}_{2}\right], T, S, P\right)$ & atm & $\begin{array}{l}\text { in situ oceanic carbon dioxide partial pressure as a function of carbon dioxide } \\
\text { concentration, temperature, salinity, and hydrostatic pressure }\end{array}$ & Sect. 2.1.1, Eq. (5) \\
\hline$S$ & & salinity & Sect. 2.1.1, Eq. (10) \\
\hline $\mathrm{EF}$ & & $\begin{array}{l}\text { enhancement factor: factor by which the true } \mathrm{CO}_{2} \text { export flux } E^{\mathrm{CO}_{2}} \text { is higher } \\
\text { than the hypothetical, diffusion only flux } E_{\mathrm{diff}}^{\mathrm{CO}_{2}} \text {. EF is a function of } L^{\mathrm{CO}_{2}}, T \text {, } \\
S, P \text { and pH. }\end{array}$ & $\begin{array}{l}\text { Sect. } 2.1 .2 \text {, defined in Eqs } \\
10 \text { and } 9\end{array}$ \\
\hline $\mathrm{pH}_{\text {freescale }}$ & & $\mathrm{pH}$ value on the "free" pH scale (Dickson, 1984) & Sect. 2.1.2, Eq. (10) \\
\hline$a_{k}$ & $\mathrm{~cm}$ & $\begin{array}{l}\text { reacto-diffusive length scale: a relation between the diffusion speed (diffusion } \\
\text { coefficient) and the reaction-speed (rate constants) of the considered carbonate } \\
\text { system reactions }\end{array}$ & $\begin{array}{l}\text { Sect. 2.1.2, defined in } \\
\text { Eq. (11) }\end{array}$ \\
\hline$k_{+1}$ & $\mathrm{~s}^{-1}$ & forward rate constant of the reaction of $\mathrm{CO}_{2}$ and $\mathrm{H}_{2} \mathrm{O}$ (Eq. 7) & Sect. 2.1.2, Eq. (11) \\
\hline$k_{+4}$ & $\mathrm{~kg} \mathrm{~mol}^{-1} \mathrm{~s}^{-1}$ & forward rate constant of the reaction of $\mathrm{CO}_{2}$ and $\mathrm{OH}^{-}$(Eq. 8) & Sect. 2.1.2, Eq. (11) \\
\hline$\left[\mathrm{OH}^{-}\right]$ & $\mathrm{mol} \mathrm{kg}^{-1}$ & ambient oceanic hydroxyl ion concentration & Sect. 2.1.2, Eq. (12) \\
\hline$K_{W}$ & $\mathrm{~mol}^{2} \mathrm{~kg}^{-2}$ & ion product of water & Sect. 2.1.2, Eq. (12) \\
\hline$R \mathrm{PCO}_{2}$ & $\mu \mathrm{mol} \mathrm{s}-1 \mathrm{~cm}^{-1}$ & $\begin{array}{l}\text { oceanic } \mathrm{CO}_{2} \text { removal potential equivalent to the oceanic oxygen supply poten- } \\
\text { tial } S P_{\mathrm{O}_{2}} \text { in Hofmann et al. (2012), Eq. (7) }\end{array}$ & $\begin{array}{l}\text { Sect. 2.1.3, newly defined } \\
\text { in Eq. (16) }\end{array}$ \\
\hline$\left.p \mathrm{CO}_{2}\right|_{\mathrm{s}}$ & $\mu$ atm & $\begin{array}{l}\text { carbon dioxide partial pressure directly at the organism surface (outside of the } \\
\text { organism, but past the DBL) }\end{array}$ & Sect. 2.1 .3 \\
\hline$\left.p \mathrm{CO}_{2}\right|_{\mathrm{f}}$ & $\mu a t m$ & ambient free stream carbon dioxide partial pressure (outside of the DBL) & Sect. 2.1.3 \\
\hline$\left.p \mathrm{CO}_{2}\right|_{\mathrm{s}} ^{\max }$ & $\mu \mathrm{atm}$ & maximal value that can be assumed for $\left.p \mathrm{CO}_{2}\right|_{\mathrm{s}}$ & Sect. 2.1 .4 \\
\hline$E_{\max }^{\mathrm{CO} 2}$ & $\mu \mathrm{mol} \mathrm{s}{ }^{-1} \mathrm{~cm}^{-2}$ & $\begin{array}{l}\text { Maximal, DBL diffusion limited carbon dioxide expulsion rate per area of gas } \\
\text { exchange tissue }\end{array}$ & $\begin{array}{l}\text { Sect. } 2.2 \text {, newly defined in } \\
\text { Eq. (3) }\end{array}$ \\
\hline$u_{100}$ & $\mathrm{~cm} \mathrm{~s}^{-1}$ & free stream fluid flow velocity over gas exchange surfaces & Table 2 \\
\hline$\Delta p_{\mathrm{DBL}}$ & $\mu$ atm & $\begin{array}{l}\text { minimal }\left.\Delta p \mathrm{CO}_{2}\right|_{\text {DBL }} \text { that is able to sustain a given oxygen consumption rate } \\
\mathrm{O}_{2}\end{array}$ & $\begin{array}{l}\text { Sect. 2.3, defined in } \\
\text { Eq. (19) }\end{array}$ \\
\hline$\left.p \mathrm{CO}_{2}\right|_{\mathrm{s}} ^{\min }$ & $\mu a t m$ & minimal $\left.p \mathrm{CO}_{2}\right|_{\mathrm{s}}$ that is able to sustain a given oxygen consumption rate $E^{\mathrm{O}_{2}}$ & $\begin{array}{l}\text { Sect. 2.4, defined in } \\
\text { Eq. (20) }\end{array}$ \\
\hline$\left.p \mathrm{CO}_{2}\right|_{\mathrm{f}} ^{\max }$ & $\mu a t m$ & maximal $\left.p \mathrm{CO}_{2}\right|_{\mathrm{f}}$ that is able to sustain a given oxygen consumption rate $E^{\mathrm{O}_{2}}$ & $\begin{array}{l}\text { Sect. 2.5, defined in } \\
\text { Eq. (21) }\end{array}$ \\
\hline$\left[\mathrm{CO}_{2}\right]_{\mathrm{f}}^{\max }$ & $\mathrm{mol} \mathrm{kg}^{-1}$ & $\begin{array}{l}\text { maximal in situ oceanic carbon dioxide concentration }\left[\mathrm{CO}_{2}\right] \text { that is able to sus- } \\
\text { tain a given oxygen consumption rate } E^{\mathrm{O}_{2}}\end{array}$ & $\begin{array}{l}\text { Sect. 2.6, defined in } \\
\text { Eq. (22) }\end{array}$ \\
\hline$\left.\left[\sum \mathrm{CO}_{2}\right]\right|_{\mathrm{f}} ^{\max }$ & $\mathrm{mol} \mathrm{kg}^{-1}$ & $\begin{array}{l}\text { maximal in situ oceanic dissolved inorganic carbon concentration }\left[\sum \mathrm{CO}_{2}\right] \text { that } \\
\text { is able to sustain a given oxygen consumption rate } E^{\mathrm{O}_{2}}\end{array}$ & Sect. 2.6 \\
\hline$\left.\mathrm{pH}\right|_{\mathrm{f}} ^{\min }$ & & $\begin{array}{l}\text { maximal in situ oceanic total scale Dickson }(1984) \mathrm{pH} \text { that is able to sustain a } \\
\text { given oxygen consumption rate } E^{\mathrm{O}_{2}}\end{array}$ & Sect. 2.6 \\
\hline
\end{tabular}


Gas molecules expelled from or taken up by an organism have to traverse both, the respiratory tissue and the diffusive boundary layer (DBL) in the medium surrounding the respiratory tissue on the outside, i.e., the surrounding ocean. In general, either one of these steps can be the rate limiting step for the diffusive transport into or out of an organism.

We denote $E_{\text {diff,DBL-lim }}^{\mathrm{CO}_{2}}$ as the maximal diffusive flux if only the diffusive boundary layer would need to be traversed (no tissue barrier) and $E_{\mathrm{diff}}^{\mathrm{CO}_{2}}$ tissue-lim as the maximal diffusive flux if only the respiratory tissue would need to be traversed (no boundary layer barrier). We can then write for the diffusive flux $E_{\text {diff }}^{\mathrm{CO}_{2}}$ (in $\mu \mathrm{mol} \mathrm{s}{ }^{-1} \mathrm{~cm}^{-2}$ ) across both barriers.

$E_{\text {diff }}^{\mathrm{CO}_{2}} \leq \min \left(E_{\text {diff,,tissue-lim }}^{\mathrm{CO}_{2}}, E_{\text {diff,,DBL-lim }}^{\mathrm{CO}_{2}}\right)$

Which means, the diffusive flux across both barriers $E_{\text {diff }}^{\mathrm{CO}_{2}}$ always has to be smaller than or equal to the maximal flux that the DBL transversion permits (i.e., $E_{\mathrm{diff}}^{\mathrm{CO}_{2}}$ DBL-lim ) and we can write:

$E_{\text {diff }}^{\mathrm{CO}_{2}} \leq E_{\text {diff, DBL-lim }}^{\mathrm{CO}_{2}}$

$E_{\text {diff,DBL-lim }}^{\mathrm{CO}_{2}}$, however, can be expressed as follows:

$E_{\text {diff,DBL-lim }}^{\mathrm{CO}_{2}}=\left.\frac{D^{\mathrm{CO}_{2}} \rho_{\mathrm{SW}}}{L^{\mathrm{CO}_{2}} K 0^{\prime \mathrm{CO}_{2}}} \Delta p \mathrm{CO}_{2}\right|_{\mathrm{DBL}}$

where $\rho_{\mathrm{SW}}$ is the in situ density of seawater (calculated according to Millero and Poisson (1981) as implemented in Hofmann et al. (2010)) in $\mathrm{kg} \mathrm{cm}^{-3}, D^{\mathrm{CO}_{2}}$ is the molecular diffusion coefficient for $\mathrm{CO}_{2}$ in $\mathrm{cm}^{2} \mathrm{~s}^{-1}$, calculated from temperature and salinity, e.g., as given in Boudreau (1996, Chapter 4$), L^{\mathrm{CO}_{2}}$ is the DBL thickness in cm, $\Delta p \mathrm{CO}_{\left.2\right|_{\mathrm{DBL}}}$ in $\mu$ atm is the partial pressure difference across the DBL, and where $\mathrm{KO}^{\prime} \mathrm{CO}_{2}$ is the apparent Henry's constant for $\mathrm{CO}_{2}$ in mol kg${ }^{-1} \mathrm{~atm}^{-1}\left(=\mu \mathrm{mol} \mathrm{kg}{ }^{-1} \mu \mathrm{atm}^{-1}\right)$ at in situ conditions:

$K 0^{\prime \mathrm{CO}_{2}}=\frac{\left[\mathrm{CO}_{2}\right]}{p \mathrm{CO}_{2}\left(\left[\mathrm{CO}_{2}\right], T, S, P\right)}$

$\left[\mathrm{CO}_{2}\right]$ in $\mathrm{mol} \mathrm{kg}^{-1}$ here is the $\mathrm{CO}_{2}$ concentration and in the denominator $p \mathrm{CO}_{2}\left(\left[\mathrm{CO}_{2}\right], T, S, P\right)$ in atm is the partial pressure of $\mathrm{CO}_{2}$ as a function of $\mathrm{CO}_{2}$ concentration, temperature, salinity and hydrostatic pressure, first calculated in the conventional way from $\left[\mathrm{CO}_{2}\right]$ using the common mass unit Henry's constant $K 0$, calculated according to Weiss (1974) using potential temperature $(\theta$, Bryden, 1973; Fofonoff, 1977), and the fugacity coefficient for $\mathrm{CO}_{2}$ calculated as given in Zeebe and Wolf-Gladrow (2001) (restated from Koertzinger, 1999). Resulting $p \mathrm{CO}_{2}$ values are then corrected for hydrostatic pressure (calculated from given depth values according to Fofonoff and Millard, 1983) according to Enns et al. (1965).

Combining Eqs. (3) and (4) results in:

$E_{\text {diff }}^{\mathrm{CO}_{2}} \leq \frac{D^{\mathrm{CO}_{2}} \rho_{\mathrm{SW}}}{L^{\mathrm{CO}_{2}} K 0^{\prime \mathrm{CO}_{2}}} \Delta p \mathrm{CO}_{\left.2\right|_{\mathrm{DBL}}}$
With this inequality, we can calculate an upper boundary for the diffusive flux of $\mathrm{CO}_{2}$ out of an animal, as posed by the barrier of the diffusive boundary layer in the oceanic environment surrounding it. The true flux will always be lower than this upper boundary and might be limited by tissue transport (tissue transport limitation is an important and interesting field of research, however, it is out of the scope and intention of the paper presented here).

As effective as gas transport in an animal tissue might be (and this includes extreme cases where enzyme based tissuetransport enhancement mechanisms have evolved), the ultimate limit is still the maximal rate that the diffusive boundary layer surrounding the organism allows. Using Eq. (6), we investigate this ultimate limit here. Furthermore, and more importantly, this approach allows us to define organismindependent metrics to describe and compare various oceanic environments with one another - which is the main goal of this paper.

\subsubsection{Deriving the equations step 2: including boundary layer $\mathrm{CO}_{2}$ reactivity using the enhancement factor EF}

In contrast to the $\mathrm{O}_{2}$ case, $\mathrm{CO}_{2}$ is reactive in seawater via acid-base equilibration reactions of the carbonate system (e.g. Zeebe and Wolf-Gladrow, 2001), the most important ones being:

$\mathrm{CO}_{2}+\mathrm{H}_{2} \mathrm{O}<->\mathrm{HCO}_{3}^{-}+\mathrm{H}^{+}$

$\mathrm{CO}_{2}+\mathrm{OH}^{-}<->\mathrm{HCO}_{3}^{-}$

While these reactions and other aquatic acid-base equilibration reactions can be treated in great detail (e.g. Hofmann et al., 2008, 2010), very reasonable approximations (Zeebe and Wolf-Gladrow, 2001) give a dimensionless "enhancement factor" EF that well describes the enhancement of diffusive $\mathrm{CO}_{2}$ transport by the above reactions

$\mathrm{EF}=\frac{E^{\mathrm{CO}_{2}}}{E_{\text {diff }}^{\mathrm{CO}_{2}}}=f\left(L^{\mathrm{CO}_{2}}, T, S, P, \mathrm{pH}_{\text {free scale }}\right)$

where $E^{\mathrm{CO}_{2}}$ represents the true $\mathrm{CO}_{2}$ flux including the effect of chemical reactions and $E_{\mathrm{CO}_{2}}^{\text {diff }}$ is the hypothetical diffusive flux that would occur if $\mathrm{CO}_{2}$ were not chemically reactive in seawater, as described in Sect. 2.1.1. The dimensionless factor EF is a function of the thickness of the diffusive boundary layer for $\mathrm{CO}_{2}, L^{\mathrm{CO}_{2}}$ in cm, temperature $T$ in ${ }^{\circ} \mathrm{C}$, salinity $S$, hydrostatic pressure $P$ in bar, and the ambient $\mathrm{pH}$ on the free scale $\mathrm{pH}_{\text {free scale. It can be calculated for plane geome- }}$ try, which is used here as a first order approximation for any biologic gas exchange surface, as follows:

$\mathrm{EF}=\frac{L^{\mathrm{CO}_{2}}}{a_{k}} \operatorname{coth}\left(\frac{L^{\mathrm{CO}_{2}}}{a_{k}}\right)$ 
with $a_{k}$ in $\mathrm{cm}$ being the reacto-diffusive length scale for $\mathrm{CO}_{2}$ diffusion and the reactions given in Eqs. (7) and (8), which can be calculated as:

$a_{k}=\sqrt{\frac{D^{\mathrm{CO}_{2}}}{k_{+1}+k_{+4}\left[\mathrm{OH}^{-}\right]}}$

Again, the molecular diffusion coefficient for $\mathrm{CO}_{2}$ in $\mathrm{cm}^{2} \mathrm{~s}^{-1}, D^{\mathrm{CO}_{2}}$, can be calculated as a function of $S, T$ and $P . k_{+1}$ is the forward rate constant in $\mathrm{s}^{-1}$ of the reaction of $\mathrm{CO}_{2}$ and $\mathrm{H}_{2} \mathrm{O}$ (Eq. 7) and $k_{+4}$ is the forward rate constant in $\mathrm{kg} \mathrm{mol}^{-1} \mathrm{~s}^{-1}$ of the reaction of $\mathrm{CO}_{2}$ and $\mathrm{OH}^{-}$(Eq. 8), both $\left(k_{+1}\right.$ and $\left.k_{+4}\right)$ can be calculated as functions of temperature $T$, as given in Zeebe and Wolf-Gladrow (2001). $\left[\mathrm{OH}^{-}\right]$is the hydroxyl ion concentration in $\mathrm{mol} \mathrm{kg}^{-1}$ calculated as

$\left[\mathrm{OH}^{-}\right]=\frac{K_{W}}{10^{-} \mathrm{pH}_{\text {free scale } \frac{\mathrm{mol}}{\mathrm{kg}}}}$

where $K_{W}$ in $\mathrm{mol}^{2} \mathrm{~kg}^{-2}$ is the ion product of water, calculated ( $K_{W}$ is here calculated after Millero (1995) as implemented in Hofmann et al. (2010)) as a function of temperature $T$ and salinity $S$.

While the notion of considering $\mathrm{CO}_{2}$ reactivity in the $\mathrm{DBL}$ is not a new one (Bolin, 1960; Quinn and Otto, 1971; Emerson, 1975), the well-known textbook by Zeebe and WolfGladrow (2001) restated and summarised the concept in a concise manner: we, thus, use the definition and nomenclature presented there. As Eq. (11) features kinetic reaction constants and not equilibrium constants and, therefore, represents a relation between the kinetics of diffusion and $\mathrm{CO}_{2}$ reaction in seawater, the "enhancement factor" concept is ideally suited to treat cases where the $\mathrm{CO}_{2}$ system will not reach equilibrium in the DBL, but $\mathrm{CO}_{2}$ reactivity still plays a major role in enhancing the diffusive $\mathrm{CO}_{2}$ flux through the DBL. To illustrate the orders of magnitude of quantities involved in typical cases: typical values for diffusion coefficient $D^{\mathrm{CO}_{2}}$ are on the order of $10^{-9} \mathrm{~m}^{2} \mathrm{~s}^{-1}$ and boundary layer thicknesses usually range between $10^{-2}$ to $10^{-4} \mathrm{~m}$, while characteristic times for the reaction of $\mathrm{CO}_{2}$ and $\mathrm{H}_{2} \mathrm{O}$ (Eq. 7) are in the order of $10 \mathrm{~s}$ and for the reaction of $\mathrm{CO}_{2}$ and $\mathrm{OH}^{-}$ (Eq. 8) in the order of $10^{-7} \mathrm{~s}$ (all values here: Zeebe and Wolf-Gladrow, 2001) - so in most cases there will be enough time for $\mathrm{CO}_{2}$ to significantly react with the carbonate system of seawater, a fact that is reflected in respective EF values $>1$.

Note that Zeebe and Wolf-Gladrow (2001) also define a "spherical" version of EF which is meant for microorganisms where the effective thickness of the DBL (i.e., $L^{\mathrm{CO}_{2}}$ here) is equal to the radius of the sphere (e.g., Zeebe and Wolf-Gladrow, 2001). While being a valuable description for plankton and unicellular algae, for any other (i.e., macroscopic) organism, the planar description is more appropriate: while there will be a specific description for each animal shape, gas exchange tissue shape and size, mode of swimming and pumping, etc., there will always be a dependency on the flow velocity across the gas exchange tissue. The planar surface description is the most generic and widely applicable description that allows for such a parameterisation and we, therefore, use it here.

Using EF we can write an equation for the $\mathrm{CO}_{2}$ export flux from an organism (in $\mu \mathrm{mol} \mathrm{s} \mathrm{cm}^{-1}$ ), considering both diffusion and $\mathrm{CO}_{2}$ reactivity in seawater

$E^{\mathrm{CO}_{2}}=E_{\text {diff }}^{\mathrm{CO}_{2}} \mathrm{EF}$

Using Eq. 6, for $E_{\text {diff }}^{\mathrm{CO}_{2}}$, this means:

$E^{\mathrm{CO}_{2}} \leq \frac{D^{\mathrm{CO}_{2}} \rho_{\mathrm{SW}} K 0^{\prime \mathrm{CO}_{2}} \mathrm{EF}}{L^{\mathrm{CO}_{2}}} \Delta p \mathrm{CO}_{\left.2\right|_{\mathrm{DBL}}}$

\subsubsection{Defining $R P_{\mathrm{CO}_{2}}$ equivalently to $S P_{\mathrm{O}_{2}}$}

In order to define a quantity similar to the oceanic oxygen supply potential $S P_{\mathrm{O}_{2}}$ in the oxygen companion paper (Hofmann et al., 2012, Eq. 7), we now multiply both sides of the equation with the DBL thickness $L^{\mathrm{CO}_{2}}$.

$E^{\mathrm{CO}_{2}} L^{\mathrm{CO}_{2}} \leq D^{\mathrm{CO}_{2}} \rho_{\mathrm{SW}} K 0^{\prime \mathrm{CO}_{2}}$ EF $\Delta p \mathrm{CO}_{\left.2\right|_{\mathrm{DBL}}}$

The equivalent mathematical reformulation for $\mathrm{O}_{2}$ (transition from Eqs. (5)-(6) in Hofmann et al., 2012) yields a righthand side of the equation (Eq. 6 in Hofmann et al., 2012), that is not a function of the DBL thickness anymore. In the companion paper, this allows us to define the oceanic oxygen supply potential $S P_{\mathrm{O} 2}$ as a purely oceanic property that is independent of any animal specific boundary layer thickness. In the $\mathrm{CO}_{2}$ case here, $\mathrm{EF}$ on the right-hand side of Eq. (15) is still a function of the DBL thickness. To obtain a quantity comparable to the $\mathrm{CO}_{2}$ case, we nevertheless define the oceanic $\mathrm{CO}_{2}$ removal potential (in $\mu \mathrm{mol} \mathrm{s}{ }^{-1} \mathrm{~cm}^{-1}$ ) by considering the limiting case, i.e., the maximal upper boundary for the $\mathrm{CO}_{2}$ removal rate, as follows:

$R P_{\mathrm{CO}_{2}}:=D^{\mathrm{CO}_{2}} \rho_{\mathrm{SW}} K 0^{\prime \mathrm{CO}_{2}}$ EF $\Delta p \mathrm{CO}_{\left.2\right|_{\mathrm{DBL}}}$

where $R P_{\mathrm{CO}_{2}}$ depends on a model description for the DBL. Again, we use a generic planar surface description as given in Table 2 (adapted for $\mathrm{CO}_{2}$ from Hofmann et al. (2012), Table 1).

While being simplified, the description for the DBL thickness implemented here (Table 2 ) reproduces the general nonlinear dependency of $L^{\mathrm{CO}_{2}}$ on the fluid flow velocity $u_{100}$, and the dependency of this relation on temperature. Although for real animals, considerable fine structure of gas exchange tissues may exist, the physical forcing required to change the thickness of this layer will follow the same physical laws. The limit case of $u_{100} \rightarrow 0$ would yield $L^{\mathrm{CO}_{2}} \rightarrow \infty$. This example formulation for $L^{\mathrm{CO}_{2}}$ as a function of $u_{100}$ is, thus, not defined in a physically meaningful way for zero flow velocity and should not be used for the completely stagnant water 
Table 2. Expressing the DBL thickness $L$ as a function of water flow velocity: a generic planar surface description.

The DBL thickness for $\mathrm{CO}_{2} L^{\mathrm{CO}_{2}}$ can be expressed as the fraction of the temperature-dependent molecular diffusion coefficient $D^{\mathrm{CO}_{2}}$ for $\mathrm{CO}_{2}$ in $\mathrm{cm}^{2} \mathrm{~s}^{-1}$, calculated from temperature and salinity as given in Boudreau (1996, Chapter 4) using the implementation in the R package marelac (Soetaert et al., 2010), and the mass transfer coefficient $K_{\mathrm{CO}_{2}}$ (Santschi et al., 1991; Boudreau, 1996)

$L^{\mathrm{CO}_{2}}=\frac{D^{\mathrm{CO}_{2}}}{K_{\mathrm{CO}_{2}}}$

$K_{\mathrm{CO}_{2}}$ can be calculated for $\mathrm{CO}_{2}$ from the water-flow induced shear velocity $u^{\prime}$ in $\mathrm{cm} \mathrm{s}^{-1}$ and the dimensionless Schmidt number $S c$ for $\mathrm{CO}_{2}$ (as calculated by linearly interpolating two temperature dependent formulations for $S=35$ and $S=0$ in Wanninkhof (1992) with respect to

$K_{\mathrm{CO}_{2}}=a u^{\prime} S c_{\mathrm{CO}_{2}}^{-b}$

with parameters $a$ and $b$ : Santschi et al. (1991): $a=0.078, b=\frac{2}{3}$; Shaw and Hanratty (1977) (also given in Boudreau, 1996): $a=0.0889, b=0.704$; Pinczewski and Sideman (1974) as given in Boudreau (1996): $a=0.0671, b=\frac{2}{3}$; Wood and Petty (1983) as given in Boudreau (1996): $a=0.0967, b=\frac{7}{10}$. Due to small differences we use averaged results of all formulations.

$u^{\prime}$ can be calculated from the ambient current velocity at $100 \mathrm{~cm}$ away from the exchange surface $u_{100}$ and the dimensionless drag coefficient $c_{100}$ (Sternberg, 1968; Santschi et al., 1991; Biron et al., 2004)

$u^{\prime}=u_{100} \sqrt{c_{100}}$

$c_{100}$ is calculated from the water flow velocity $u_{100}$ as (Hickey et al., 1986; Santschi et al., 1991)

$c_{100}=10^{-3}\left(2.33-0.0526\left|u_{100}\right|+0.000365\left|u_{100}\right|^{2}\right)$

case. A minimum of $u_{100}=0.5 \mathrm{~cm} \mathrm{~s}^{-1}$ can be seen as an operational lower limit.

While the term $R P_{\mathrm{CO}_{2}}$ itself does depend on the DBL properties, $R P_{\mathrm{CO}_{2}}$ with $\mathrm{EF}=1$ can be interpreted as a $h y$ pothetical "purely diffusive" oceanic $\mathrm{CO}_{2}$ removal potential, a quantity that is not dependent on a DBL model description. However, due to the high reactivity of $\mathrm{CO}_{2}$ in seawater, the applicability of $R P_{\mathrm{CO}_{2}}$ with $\mathrm{EF}=1$ is limited. The more realistic quantity with real physico-chemical meaning, however, is $R P_{\mathrm{CO}_{2}}$ with $\mathrm{EF}$ as calculated above in Eq. (10). We point out that the planar boundary layer property $L^{\mathrm{CO}_{2}}$ description here (as well as the planar EF description) is meant to be generic for large scale oceanic comparison and works very well for all, but the very smallest (i.e., microbial) scales (Zeebe and Wolf-Gladrow, 2001), which are not considered here. The sensitivity of our calculations with respect to relative fluid flow velocities across gas exchange tissues (the combination of ambient current flow and animal activity like swimming or pumping, see Sect. 3.1) are explored in Sect. 3.1 and Appendix A.

$R P_{\mathrm{CO}_{2}}$ depends on the $\mathrm{CO}_{2}$ partial pressure differential $\Delta p \mathrm{CO}_{\left.2\right|_{\mathrm{DBL}}}=\left(\left.p \mathrm{CO}_{2}\right|_{\mathrm{s}}-\left.p \mathrm{CO}_{2}\right|_{\mathrm{f}}\right)$ across the DBL with $\left.p \mathrm{CO}_{2}\right|_{\mathrm{f}}$ being the ambient free stream $p \mathrm{CO}_{2}$ value and $\left.p \mathrm{CO}_{2}\right|_{\mathrm{s}}$ being the $p \mathrm{CO}_{2}$ value directly at the organism surface. Here, we investigate outer envelopes of diffusive $\mathrm{CO}_{2}$ export limitations, i.e., we are interested in maximal values for $R P_{\mathrm{CO}_{2}} .\left.\Delta p \mathrm{CO}_{2}\right|_{\mathrm{DBL}}$ and, thus, $R P_{\mathrm{CO}_{2}}$ are maximal when $\left.p \mathrm{CO}_{2}\right|_{\mathrm{s}}$ is maximal.

\subsection{4 $\left.\mathrm{pCO}_{2}\right|_{\mathrm{s}} ^{\max }$, an exemplary maximal value for the $\mathrm{CO}_{2}$ partial pressure in molecular contact with an organism}

The sensitivity of marine animals to elevated internal $p \mathrm{CO}_{2}$ levels varies with species and life stage. Absolute limits are hard to define, as knowledge about the effects of acute hypercapnia is still limited (see, e.g., Caldeira et al., 2005; Poertner et al., 2005). Almost nothing is know about the limits for $p \mathrm{CO}_{2}$ or $\mathrm{pH}$ in diffusive molecular contact with the outside of the gas exchange surface of an organism. However, to calculate maximal $R P_{\mathrm{CO}_{2}}$ values, Eq. (16) requires a maximal value for $\left.p \mathrm{CO}_{2}\right|_{\mathrm{s}}$, which exactly represents this maximal $p \mathrm{CO}_{2}$ directly at the (gas exchange) surface of an organism. For the example calculations given here, comparing various oceanic regions amongst each other, we use one single, constant value $\left.p \mathrm{CO}_{2}\right|_{\mathrm{s}}=\left.p \mathrm{CO}_{2}\right|_{\mathrm{s}} ^{\max }=5000 \mu \mathrm{atm}$. If attained in the external medium, this $p \mathrm{CO}_{2}$ would produce effects such as narcosis and mortality in sensitive organisms (Caldeira et al., 2005).

Since, a certain limit $p \mathrm{CO}_{2}$ value in the free stream entails a higher $p \mathrm{CO}_{2}$ value in molecular contact with the organism surface, and effects for $p \mathrm{CO}_{2}=5000 \mu \mathrm{atm}$ are reported in Caldeira et al. (2005) for only the most sensitive organisms, choosing $\left.p \mathrm{CO}_{2}\right|_{\mathrm{s}}=\left.p \mathrm{CO}_{2}\right|_{\mathrm{s}} ^{\max }=5000 \mu$ atm is a rather low estimate for a limit value, likely overestimating the $\mathrm{CO}_{2}$ removal limitation in our calculations. 
While we are aware that $\left.p \mathrm{CO}_{2}\right|_{\mathrm{s}}=\left.p \mathrm{CO}_{2}\right|_{\mathrm{s}} ^{\max }=5000 \mu$ atm is an assumption serving mainly exemplary purposes here, using one single constant value effectively also removes species dependency from the calculation of $R P_{\mathrm{CO}_{2}}$. The calculation may easily be repeated by substituting known species specific values. The sensitivity of our calculations with respect to $\left.p \mathrm{CO}_{2}\right|_{\mathrm{s}}$ are explored below.

\subsection{Maximal $\mathrm{CO}_{2}$ diffusion limited metabolic rate $\mathrm{E}_{\max }^{\mathrm{CO}_{2}}$}

Analogous to the oxygen quantity $\mathrm{E}_{\max }$ (Hofmann et al., 2012, Eq. 9), we can define a maximal metabolic rate $\left(\mathrm{CO}_{2}\right.$ export and, thus, $\mathrm{O}_{2}$ import) that diffusive limitation of $\mathrm{CO}_{2}$ export would allow:

$\mathrm{E}_{\max }^{\mathrm{CO}_{2}}:=\frac{\mathrm{RP}_{\mathrm{CO}_{2}}}{L^{\mathrm{CO}_{2}}}=\left.\frac{D^{\mathrm{CO}_{2}} \rho_{\mathrm{SW}} K 0^{\prime \mathrm{CO}_{2}} \mathrm{EF}}{L^{\mathrm{CO}_{2}}} \Delta p \mathrm{CO}_{2}\right|_{\mathrm{DBL}}$

Here, we use the same generic description for $L^{\mathrm{CO}_{2}}$ (given in Table 2 as used for the EF definition Eq. 10.)

\subsection{Required $\left.\Delta p \mathrm{CO}_{2}\right|_{\mathrm{DBL}}$ for a given $E^{\mathrm{O}_{2}}$}

Similar to the $\mathrm{O}_{2}$ quantity $C_{\mathrm{f}}$ (Hofmann et al., 2012, Eq. 12), we can define a quantity that is not dependent on the external $\mathrm{CO}_{2}$ content of the water. To explicitly include the dependence of gas exchange on partial pressure and the dependency of partial pressure on hydrostatic pressure (Enns et al., 1965), we assume a given oxygen uptake rate $E^{\mathrm{O}_{2}}$ (in $\mu \mathrm{mol} \mathrm{s} \mathrm{cm}^{-1}$ ), experimentally determined at diffusivities and DBL thicknesses equal to the respective in situ values, but at one atmosphere.

As stated in Eq. (1), we assume $E^{\mathrm{CO}_{2}}=E^{\mathrm{O}_{2}}$, with the flux directions defined as opposite. Therefore, we can calculate the required $\mathrm{CO}_{2}$ partial pressure differential (in $\mu \mathrm{atm}$ ) that is able to support a given metabolic rate $\left(\mathrm{O}_{2}\right.$ import and, thus, $\mathrm{CO}_{2}$ export) by making use of Eq. (14).

$\left.\Delta p \mathrm{CO}_{2}\right|_{\mathrm{DBL}} \geq \frac{E^{\mathrm{O}_{2}} L^{\mathrm{CO}_{2}}}{D^{\mathrm{CO}_{2}} \rho_{\mathrm{SW}} K 0_{E}^{\prime \mathrm{CO}_{2}} \mathrm{EF}}$

where $K 0_{E}^{\prime \mathrm{CO}_{2}}$ is the apparent Henry's constant (calculated as eluded to above) at "experimental" conditions, i.e., at the conditions at which $E_{\mathrm{O}_{2}}$ was determined, most notably one atmosphere. Again, considering the limiting case of a minimal partial pressure differential that satisfies Eq. (18), we can define as follows:

$\Delta p_{\mathrm{DBL}}:=\frac{E^{\mathrm{O}_{2}} L^{\mathrm{CO}_{2}}}{D^{\mathrm{CO}_{2}} \rho_{\mathrm{SW}} K 0_{E}^{\prime \mathrm{CO}_{2}} \mathrm{EF}}$

For exemplary purposes, we use $E^{\mathrm{O}_{2}}=20 \times 10^{-7} \mu \mathrm{mol}$ $\mathrm{s}^{-1} \mathrm{~cm}^{-2}$, consistent with the oxygen companion paper Hofmann et al. (2012), e.g., Sect. 3.3. and Fig. 5.

\subsection{Required minimal $\left.p \mathrm{CO}_{2}\right|_{\mathrm{s}}$ for given external condi- tions and given $E^{\mathrm{O}_{2}}$}

Having calculated the minimally required $p \mathrm{CO}_{2}$ gradient $\Delta p_{\mathrm{DBL}}$ to sustain a given $E^{\mathrm{O}_{2}}$ (and associated $E^{\mathrm{CO}_{2}}$ ) from Eq. (19), a minimally required $p \mathrm{CO}_{2}$ (in $\mu \mathrm{atm}$ ) in molecular contact with the gas exchange surface of the organism can be calculated by using a given, pressure corrected (Enns et al., 1965) free stream (i.e., bulk ocean) $\mathrm{CO}_{2}$ partial pressure $\left.p \mathrm{CO}_{2}\right|_{\mathrm{f}}$ :

$\left.p \mathrm{CO}_{2}\right|_{\mathrm{s}} ^{\min }=\left.p \mathrm{CO}_{2}\right|_{\mathrm{f}}+\Delta p_{\mathrm{DBL}}$

\subsection{Maximal $\left.p \mathrm{CO}_{2}\right|_{\mathrm{f}}$ for given $E^{\mathrm{O}_{2}}$ and assumed $\left.p \mathrm{CO}_{2}\right|_{\mathrm{s}}$}

Similarly, the maximal external free stream $p \mathrm{CO}_{2}$ permitting the efflux required for metabolic balance can be calculated. If the (maximal) $\mathrm{CO}_{2}$ partial pressure $\left.p \mathrm{CO}_{2}\right|_{\mathrm{s}}$ in contact with the respiratory surface that permits normal functioning of the animal is given, then:

$\left.p \mathrm{CO}_{2}\right|_{\mathrm{f}} ^{\max }=\left.p \mathrm{CO}_{2}\right|_{\mathrm{s}}-\Delta p_{\mathrm{DBL}}$

For illustrative purposes, we again assume $\left.p \mathrm{CO}_{2}\right|_{\mathrm{s}}=\left.p \mathrm{CO}_{2}\right|_{\mathrm{s}} ^{\max }=5000 \mu \mathrm{atm}$ for calculations here.

\subsection{Limiting external conditions for given $E^{\mathrm{O}_{2}}$ and assumed $\left.p \mathrm{CO}_{2}\right|_{\mathrm{s}}$}

The quantity $\left.p \mathrm{CO}_{2}\right|_{\mathrm{f}} ^{\max }$ can then be used to calculate the maximal, in situ, $\mathrm{CO}_{2}$ concentration in the free stream bulk medium that is required for an experimentally observed $\mathrm{CO}_{2}$ demand to be supported as in:

$\left[\mathrm{CO}_{2}\right]_{\mathrm{f}}^{\max }=\left.p \mathrm{CO}_{2}\right|_{\mathrm{f}} ^{\max } K 0^{\prime \mathrm{CO}_{2}}$

Where $K 0^{\prime} \mathrm{CO}_{2}$ in mol kg${ }^{-1} \mathrm{~atm}^{-1}$ is the apparent in situ Henry's constant as calculated above (Eq. 5).

The property $\left[\mathrm{CO}_{2}\right]_{\mathrm{f}}^{\max }$ can then be used to calculate limiting bulk fluid ocean conditions (e.g., maximal $\left[\sum \mathrm{CO}_{2}\right]$ : $\left.\left[\sum \mathrm{CO}_{2}\right]\right|_{\mathrm{f}} ^{\max }$, minimal total scale $\mathrm{pH}:\left.\mathrm{pH}\right|_{\mathrm{f}} ^{\min }$, etc.) that can balance the required $\mathrm{CO}_{2}$ consumption. Bulk fluid conditions here are calculated in the programming language $\mathrm{R}$ with the acid-base chemistry routines implemented in the R extension package AquaEnv (Hofmann et al., 2010), with the Millero et al. (2006) equilibrium constants for the carbonate system and all other constants being the standard AquaEnv formulations with references given there. $\left[\sum(\mathrm{BOH})_{3}\right],\left[\sum \mathrm{H}_{2} \mathrm{SO}_{4}\right]$, and $\left[\sum \mathrm{HF}\right]$ are estimated from salinity $\mathrm{S}$ as given in DOE (1994) and Dickson et al. (2007). Conversions between free scale and total scale $\mathrm{pH}$ are done as implemented in AquaEnv.

\subsection{External conditions: present-day and future values}

In order to compare our derived example limiting freestream conditions (maximal $p \mathrm{CO}_{2},\left[\sum \mathrm{CO}_{2}\right]$, and minimal 

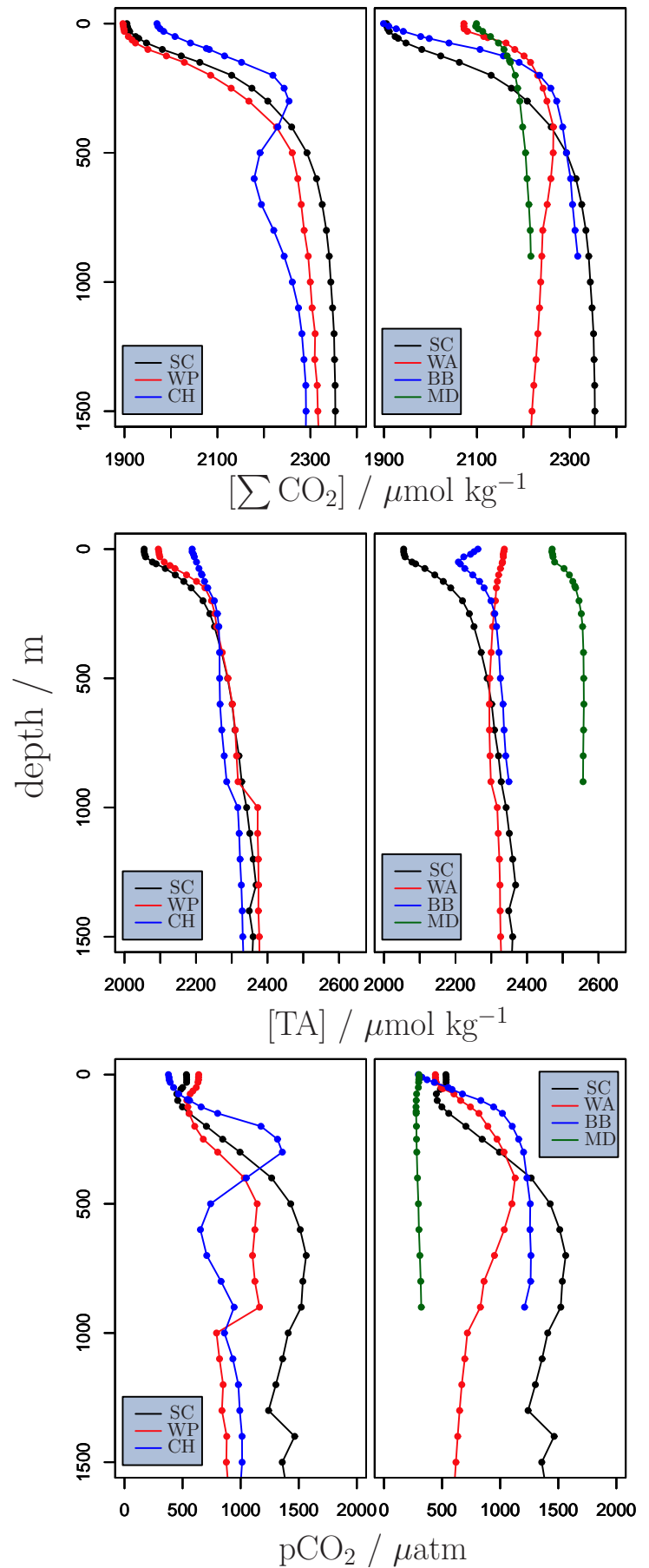

Fig. 1. Oceanographical data taken from Goyet et al. (2000) and limited to shallower depths when discontinuities occurred deeper. Top row: total dissolved inorganic carbon concentration $\left[\sum \mathrm{CO}_{2}\right]$. Central row: total alkalinity concentration [TA]. Bottom row: carbon dioxide partial pressure $p \mathrm{CO}_{2}$. (SC: Southern California $\left(120.5^{\circ} \mathrm{W}, 29.50^{\circ} \mathrm{N}\right)$; $\mathrm{CH}$ : Chile $\left(75.5^{\circ} \mathrm{W}, 33.5^{\circ} \mathrm{S}\right)$; WP: Western Pacific $\left(126.5^{\circ} \mathrm{E}, 11.5^{\circ} \mathrm{N}\right)$, WA: Western Africa $\left(6.5^{\circ} \mathrm{E}\right.$, $\left.15.5^{\circ} \mathrm{S}\right)$, MD: Mediterranean $\left(18.5^{\circ} \mathrm{E}, 35.5^{\circ} \mathrm{N}\right)$; BB: Bay of Ben$\left.\operatorname{gal}\left(87.5^{\circ} \mathrm{E}, 18.5^{\circ} \mathrm{N}\right)\right)$.
$\mathrm{pH})$ to present-day conditions we use data from the alkalinity and dissolved inorganic carbon climatology of Goyet et al. (2000) for a location off the coast of Southern California $\left(\mathrm{SC}: 120.5^{\circ} \mathrm{W}, 29.50^{\circ} \mathrm{N}\right)$ and other stations around the world $\left(\mathrm{CH}\right.$ : Chile $\left(75.5^{\circ} \mathrm{W}, 33.5^{\circ} \mathrm{S}\right)$; WP: Western Pacific $\left(126.5^{\circ} \mathrm{E}, 11.5^{\circ} \mathrm{N}\right)$, WA: Western Africa $\left(6.5^{\circ} \mathrm{E}, 15.5^{\circ} \mathrm{S}\right)$, MD: Mediterranean $\left(18.5^{\circ} \mathrm{E}, 35.5^{\circ} \mathrm{N}\right)$; BB: Bay of Bengal $\left(87.5^{\circ} \mathrm{E}, 18.5^{\circ} \mathrm{N}\right)$ ), consistent with the oxygen companion paper Hofmann et al. (2012) (Sect. 4 and captions to Figs. 13 and 5-7, and Table 2). Particularly, the Southern California region is selected since it is well studied, and the eastern Pacific region shows strong vertical gradients in both $\mathrm{CO}_{2}$ and $\mathrm{CO}_{2}$, thus, encompassing a wide range of oceanic values. Depth profiles of $\mathrm{CO}_{2}$ related oceanographic data for those stations is shown in Fig 1.

While all open oceanic stations are rather similar in all oceanographic variables used for our calculations (see Fig. 1), the Mediterranean station (MD) has been deliberately included as an outlier to illustrate the influence of natural variability on our defined quantities. The Mediterranean is indeed a true outlier here, since it is markedly warmer $\left(\approx 14{ }^{\circ} \mathrm{C}\right.$ at $1000 \mathrm{~m}$ vs. $\approx 4{ }^{\circ} \mathrm{C}$ for the other stations at $1000 \mathrm{~m}$ (not shown)), and alkalinity values are significantly higher (Fig. 1). Since temperature is a key variable for our calculated quantities and the effect of alkalinity on the carbonate system and, thus, the enhancement factor EF plays a large role, too, the defined quantities here are markedly different for the Mediterranean than for all other stations. Details will be discussed in the following section.

For future conditions, we note that atmospheric $p \mathrm{CCO}_{2}$ may approximately triple from pre-industrial by the end of the century (e.g. IPCC, 2007; Meehl et al., 2007) with well predicted oceanic $\mathrm{CO}_{2}$ system consequences (e.g. Zeebe et al., 2008; Allison et al., 2009). We, therefore, assume a tripled $p \mathrm{CCO}_{2}$ at all depths with associated increase in $\left[\sum \mathrm{CO}_{2}\right]$ and decrease in $\mathrm{pH}$, assuming constant alkalinity while recognising that it will take several hundred years given the slow pace of oceanic mixing for changes of such scale to appear at depth.

\section{Results and discussion}

\subsection{Sensitivity of $R P_{\mathrm{CO}_{2}}$ and $\mathrm{E}_{\max }^{\mathrm{CO}_{2}}$ With respect to relative flow velocity $u_{100}$ and $\left.p \mathrm{CO}_{2}\right|_{s} ^{\max }$}

The two derived quantities central to this paper, $R P_{\mathrm{CO}_{2}}$ and $\mathrm{E}_{\max }^{\mathrm{CO}_{2}}$, are functions of the input parameters $u_{100}$ and $\left.p \mathrm{CO}_{2}\right|_{\mathrm{s}} ^{\max }$. Both parameters are not accessible via typical oceanographic data and our calculations rely on assumed constant values for those parameters. Figure 2 illustrates how our derived quantities depend on those input parameters and how those dependencies are modulated by temperature and hydrostatic pressure (here, water depth). This allows for a placement of our assumed values for $u_{100}$ and $\left.p \mathrm{CO}_{2}\right|_{\mathrm{s}} ^{\max }$ 


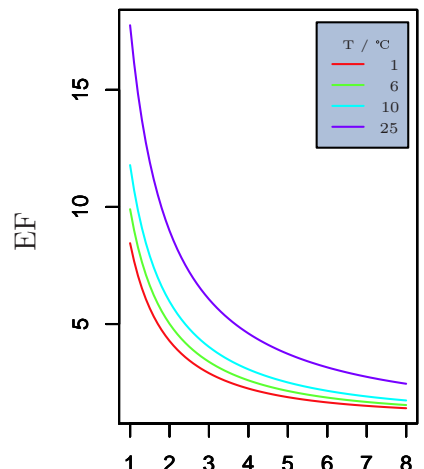

$\mathrm{u}_{100} / \mathrm{cm} \mathrm{s}^{-1}$

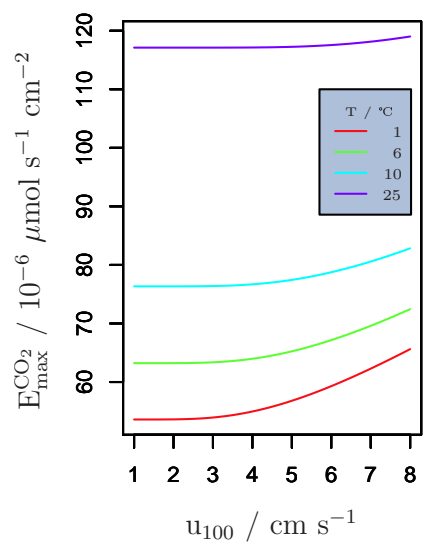

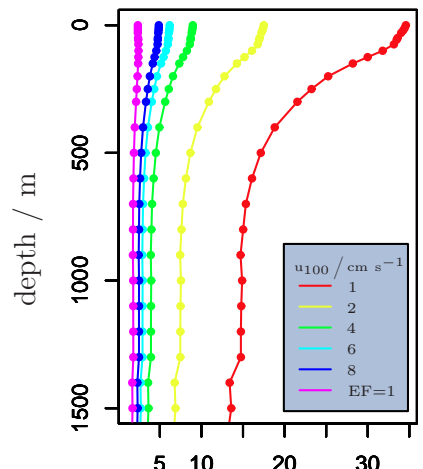

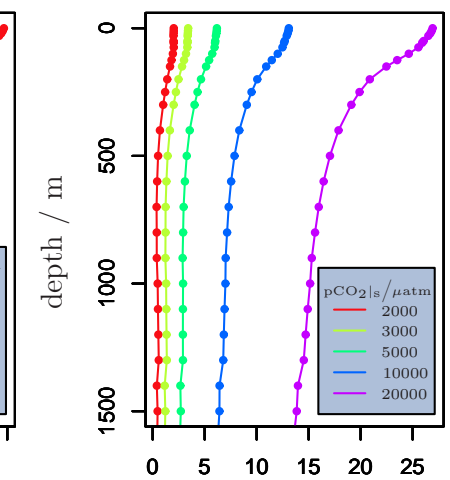

$\mathrm{RP}_{\mathrm{CO}_{2}} / 10^{-6} \mu \mathrm{mol} \mathrm{s}{ }^{-1} \mathrm{~cm}^{-1}$

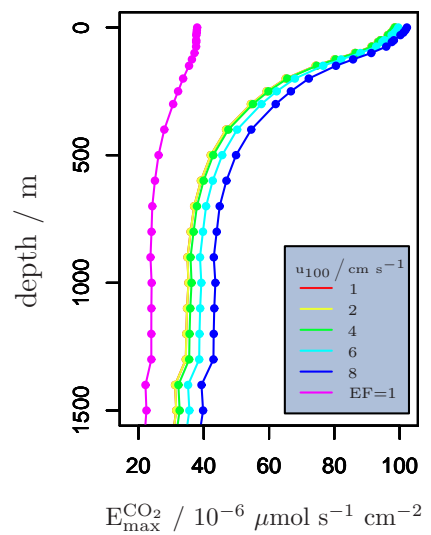

$\mathrm{RP}_{\mathrm{CO}_{2}} / 10^{-6} \mu \mathrm{mol} \mathrm{s}{ }^{-1} \mathrm{~cm}^{-1}$

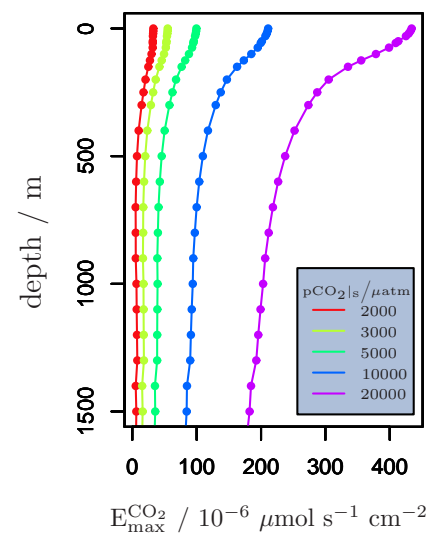

Fig. 2. Sensitivity of derived quantities $R P_{\mathrm{CO}_{2}}$ (the oceanic $\mathrm{CO}_{2}$ removal potential) and $\mathrm{E}_{\max }^{\mathrm{CO}_{2}}$ (the maximal $\mathrm{CO}_{2}$ diffusion limited metabolic rate) with respect to the free stream fluid flow velocity $u_{100}$ and the maximal $\mathrm{CO}_{2}$ partial pressure in molecular contact with the organism surface $\left(\left.\left(\left.p \mathrm{CO}_{2}\right|_{\mathrm{s}}=\right) p \mathrm{CO}_{2}\right|_{\mathrm{s}} ^{\max }\right)$. Left panel, upper row: the enhancement factor EF as a function of the free stream fluid flow velocity $u_{100}$ and temperature $T .\left[\sum \mathrm{CO}_{2}\right]=1900 \mu \mathrm{mol} \mathrm{kg}{ }^{-1},[\mathrm{TA}]=2050 \mu \mathrm{mol} \mathrm{kg}{ }^{-1}, S=34$, detph $=100 \mathrm{~m}$, latitude $=30^{\circ}$. Central panel, upper row: example depth profiles at the Southern California ( $\mathrm{SC}: 120.5^{\circ} \mathrm{W}, 29.50^{\circ} \mathrm{N}$ ) station (data from Goyet et al., 2000) of $R P_{\mathrm{CO}_{2}}$, calculated with varying free stream fluid flow velocities $u_{100}$ and assuming $\mathrm{EF}=1 .\left.p \mathrm{CO}_{2}\right|_{\mathrm{s}} ^{\max }=5000 \mu \mathrm{atm}$. Right panel, upper row: example depth profiles at the Southern California (SC) station of $R P_{\mathrm{CO}_{2}}$, calculated with varying values for the $\mathrm{CO}_{2}$ partial pressure in molecular contact with the organism surface $\left.\left(\left.p \mathrm{CO}_{2}\right|_{\mathrm{s}}=\right) p \mathrm{CO}_{2}\right|_{\mathrm{s}} ^{\max } . u_{100}=6 \mathrm{~cm} \mathrm{~s}^{-1}$. Left panel, bottom row: $\mathrm{E}_{\max }^{\mathrm{CO}_{2}}$ as a function of the free stream fluid flow velocity $u_{100}$ and temperature $T$. [ $\left.\sum \mathrm{CO}_{2}\right]=1900 \mu \mathrm{mol} \mathrm{kg}{ }^{-1},[\mathrm{TA}]=2050 \mu \mathrm{mol} \mathrm{kg}{ }^{-1}, S=34$, detph $=100 \mathrm{~m}$, latitude $=30^{\circ}, p \mathrm{CO}_{2} \mathrm{I}_{\mathrm{s}}^{\mathrm{max}}=5000 \mu \mathrm{atm}$. Central panel, bottom row: example depth profiles at the Southern California (SC) station of $\mathrm{E}_{\mathrm{max}}^{\mathrm{CO}_{2}}$, calculated with varying free stream fluid flow velocities $u_{100}$ and assuming $\mathrm{EF}=1 .\left.p \mathrm{CO}_{2}\right|_{\mathrm{s}} ^{\max }=5000 \mu \mathrm{atm} . u_{100}=6 \mathrm{~cm} \mathrm{~s}^{-1}$ for the calculation of $L^{\mathrm{CO}}{ }_{2}$ in the EF=1 case. Right panel, bottom row: Example depth profiles at the Southern California (SC) station of $\mathrm{E}_{\mathrm{max}}^{\mathrm{CO}_{2}}$, calculated with varying values for the $\mathrm{CO}_{2}$ partial pressure in molecular contact with the organism surface $\left.\left(\left.p \mathrm{CO}_{2}\right|_{\mathrm{s}}=\right) p \mathrm{CO}_{2}\right|_{\mathrm{s}} ^{\max } \cdot u_{100}=6 \mathrm{~cm} \mathrm{~s}^{-1}$.

within the range of generally possible values. Appendix A contains a more detailed description of Fig. 2. The hypothetical case assuming no $\mathrm{CO}_{2}$ reactivity $(\mathrm{EF}=1)$ is included in the central column of Fig. 2 solely for the purpose of illustrating - by comparison to results with realistic EF values the importance of $\mathrm{CO}_{2}$ reactivity in seawater.

Note that here, we consider $u_{100}$ the relative current velocity over gas exchange tissues, i.e., a combination of ambient current flow and animal activity like swimming or pumping. Respiratory gas transport across the gas-exchange surface diffusive boundary layer is a critical property, such that animals typically work to control flow and, thus, manage the supply of their respiratory rate needs. However, there clearly are cases where the physically driven external flow field is controlling (Patterson and Sebens, 1989; Shashar et al., 1993) and is reflected in the physical distribution of organisms. Basically, fluid flow velocity and changes therein can be seen as a measure of energy required to maintain respiratory needs. Whether this required energy will be supplied by the energy contained in ambient flow or is a result of (energy-consuming) animal activity like pumping or swimming is deliberately not distinguished here, as energy budget calculations inside of animals would be outside the scope of this paper.

Our treatment is valid for both, pelagic organisms and benthic dwellers. However, since for pelagics swimming and 


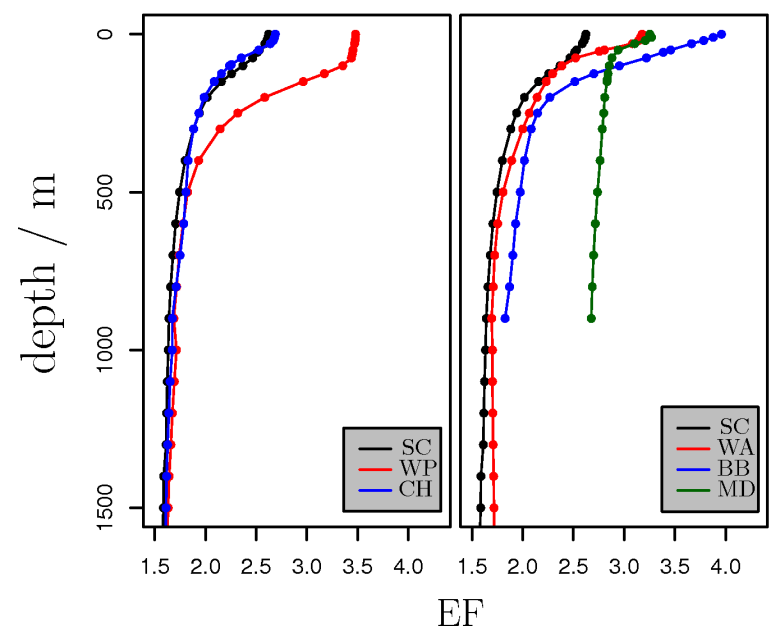

Fig. 3. Example depth profiles of EF calculated according to Eq. (10) with $u_{100}=6 \mathrm{~cm} \mathrm{~s}^{-} 1 .\left.p \mathrm{CO}_{2}\right|_{\mathrm{s}} ^{\max }=5000 \mu \mathrm{atm}$. Oceanographical data are taken from Goyet et al. (2000) and limited to shallower depths when discontinuities occurred deeper (SC: Southern California $\left(120.5^{\circ} \mathrm{W}, 29.50^{\circ} \mathrm{N}\right)$; $\mathrm{CH}$ : Chile $\left(75.5^{\circ} \mathrm{W}, 33.5^{\circ} \mathrm{S}\right)$; WP: Western Pacific $\left(126.5^{\circ} \mathrm{E}, 11.5^{\circ} \mathrm{N}\right)$, WA: Western Africa $\left(6.5^{\circ} \mathrm{E}, 15.5^{\circ} \mathrm{S}\right), \mathrm{MD}$ : Mediterranean $\left(18.5^{\circ} \mathrm{E}, 35^{\circ} \mathrm{N}\right)$; BB: Bay of Bengal $\left(87.5^{\circ} \mathrm{E}, 18.5^{\circ} \mathrm{N}\right)$ ).

pumping activities might be determining flow over their gas exchange tissues more than ambient flow, and due to the lack of detailed measured flow field data, depth profiles presented here are calculated with exemplary, constant flow velocities $\left(2 \mathrm{~cm} \mathrm{~s}^{-1}\right.$ and $6 \mathrm{~cm} \mathrm{~s}^{-1}$ - see captions of figures). While movement to ventilate gas exchange surfaces still matters, for benthic dwellers, ambient flow is more important (e.g. Feder and Burggren, 1985; Feder and Pinder, 1988; Pinder and Feder, 1990), and can be included in calculations of our quantities. For stations in Santa Monica Bay and Basin, for example, the bulk of seasonal mean ambient flow values have been reported to be between stagnant water and about $10 \mathrm{~cm} \mathrm{~s}^{-1}$ and only occasional excursions above $10 \mathrm{~cm} \mathrm{~s}^{-1}$ (Hickey et al., 2003), which is similar to flow velocities we use for our calculations here (1-8 $\mathrm{cm} \mathrm{s}^{-1}$, e.g., Fig. 2).

\section{2 $\mathrm{CO}_{2}$ export limitation quantities along depth profiles for various stations around the world ocean}

\subsection{1 $\mathrm{CO}_{2}$ reactivity: the enhancement factor $\mathrm{EF}$}

$\mathrm{CO}_{2}$ is highly reactive in seawater, expressed here by the enhancement factor EF (Fig 3), which is central to all quantities defined in this paper. Due to its dependency on $\left[\mathrm{OH}^{-}\right]$, EF depends positively on $\mathrm{pH}$ (see Eqs. 10 to 12). Therefore, EF profiles differ between stations mainly for depths shallower than $500 \mathrm{~m}$ due to different $\mathrm{pH}$ and temperature profiles. The dependency of EF on pH can also explain the markedly higher EF and, thus, $R P_{\mathrm{CO}_{2}}$ values for the Mediterranean (MD) compared to other stations, as the Mediterranean pro- file exhibits higher alkalinity (central panels of Fig. 1) and a resulting higher $\mathrm{pH}$ (not shown).

\subsubsection{Maximal DBL diffusion limited $\mathrm{CO}_{2}$ export flux: $\mathbf{E}_{\text {max }}^{\mathrm{CO}_{2}}$}

The oceanic carbon dioxide removal potential $R P_{\mathrm{CO}_{2}}$ has been introduced here to define a quantity equivalent and comparable to the oceanic oxygen supply potential $S \mathrm{P}_{\mathrm{O}_{2}}$ defined in the companion paper (Hofmann et al., 2012, Eq. 7). But the better quantity to look at to assess the ability of the ocean to remove respiratory $\mathrm{CO}_{2}$ from the organism through the diffusive boundary layer is the quantity $\mathrm{E}_{\max }^{\mathrm{CO}_{2}}$. $\mathrm{E}_{\max }^{\mathrm{CO}_{2}}$ is linearly related to $R P_{\mathrm{CO}_{2}}$ via the boundary layer thickness $L^{\mathrm{CO}_{2}}$, which is constant when calculated using a constant $u_{100}$. Depth profiles for $R P_{\mathrm{CO}_{2}}$ are given in Appendix $\mathrm{B}$ for completeness, however, only depth profiles of $\mathrm{E}_{\max }^{\mathrm{CO}_{2}}$ are shown in Fig. 4 and are discussed here.

While being obviously dominated by $\mathrm{EF}$ values, $\mathrm{E}_{\max }^{\mathrm{CO}_{2}}$ profiles show the influence of differing $p \mathrm{CO}_{2}$ profiles, especially at deeper depths (bottom panels of Fig. 1). Off the coast of Chile (station $\mathrm{CH}$ ), a clear $p \mathrm{CO}_{2}$ maximum can be identified shallower than $500 \mathrm{~m}$ (bottom left panel of Fig. 1), which results in a local dip in $\mathrm{E}_{\max }^{\mathrm{CO}_{2}}$ values (top left panel of Fig. 4), and which is due to a local $\left[\sum \mathrm{CO}_{2}\right]$ maximum (top left panel of of Fig. 1). This depth region corresponds to the local oxygen minimum in this location as described in the companion paper Hofmann et al. (2012) (Sect. 4.1., Table 2, and Fig. 1), and nicely illustrates the close relationship between local $\mathrm{O}_{2}$ and $\mathrm{CO}_{2}$ impacts.

\subsection{3 $\mathrm{CO}_{2}$ partial pressure difference needed to sustain a given metabolic rate: $\Delta p_{\mathrm{DBL}}$}

The top panels of Fig. 5 show depth profiles of $\Delta p_{\text {DBL }}$, the $\mathrm{CO}_{2}$ partial pressure differential across the DBL that is required to sustain the $\mathrm{CO}_{2}$ export resulting from a given oxygen uptake. It can clearly be seen, that $\Delta p_{\mathrm{DBL}}$ increases with depth and decreasing temperature, meaning at depth and especially in colder waters there is more driving force needed to transport $\mathrm{CO}_{2}$ through the DBL. The $\Delta p_{\mathrm{DBL}}$ profiles are rather similar for all stations, with a pronounced difference for the Mediterranean (MD) station, due to the higher temperatures and [TA] values (see also Fig. 1).

In the bottom panels of Fig. 5, depth profiles of $\left.p \mathrm{CO}_{2}\right|_{\mathrm{s}} ^{\mathrm{min}}$, the minimal $\mathrm{CO}_{2}$ partial pressure in molecular contact with the organism external surface that is required to drive a given metabolic flux across the DBL, are given. As was to be expected, the general shapes of the profiles are dominated by ambient $p \mathrm{CO}_{2}$ profiles (Fig. 1). However, at deeper depths $\left.p \mathrm{CO}_{2}\right|_{\mathrm{s}} ^{\mathrm{min}}$ profiles are clearly offset to higher values as compared to ambient $p \mathrm{CO}_{2}$ profiles (Fig. 1) due to the higher $\Delta p_{\text {DBL }}$ values at depth. 


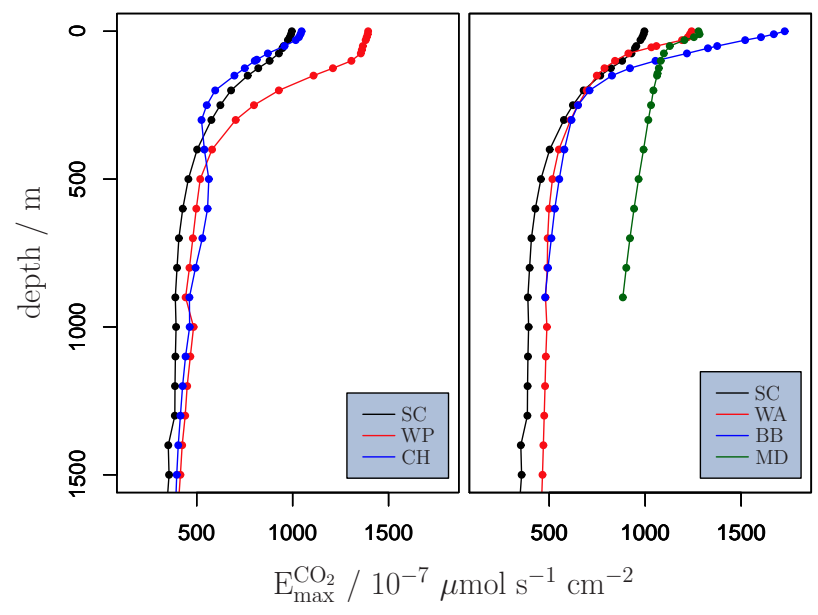

Fig. 4. Example depth profiles of the derived diffusive $\mathrm{CO}_{2}$ export limitation quantity $\mathrm{E}_{\max }^{\mathrm{CO}_{2}}$ (the maximal $\mathrm{CO}_{2}$ diffusion limited metabolic rate). $\left.p \mathrm{CO}_{2}\right|_{\mathrm{s}} ^{\max }=5000 \mu \mathrm{atm}$. Oceanographical data are taken from Goyet et al. (2000) and limited to shallower depths when discontinuities occurred deeper (SC: Southern California $\left(120.5^{\circ} \mathrm{W}, 29.50^{\circ} \mathrm{N}\right)$; $\mathrm{CH}$ : Chile $\left(75.5^{\circ} \mathrm{W}, 33.5^{\circ} \mathrm{S}\right)$; WP: Western Pacific $\left(126.5^{\circ} \mathrm{E}, 11.5^{\circ} \mathrm{N}\right)$, WA: Western Africa $\left(6.5^{\circ} \mathrm{E}\right.$, $\left.15.5^{\circ} \mathrm{S}\right)$, MD: Mediterranean $\left(18.5^{\circ} \mathrm{E}, 35.5^{\circ} \mathrm{N}\right)$; BB: Bay of Ben$\left.\operatorname{gal}\left(87.5^{\circ} \mathrm{E}, 18.5^{\circ} \mathrm{N}\right)\right)$.

\subsection{Will diffusive $\mathrm{CO}_{2}$ transport across the DBL become limiting in the future?}

From the $\left.p \mathrm{CO}_{2}\right|_{\mathrm{f}} ^{\max }$ (the maximal $p \mathrm{CO}_{2}$ in the free stream that can support a given metabolic rate) profile for the Southern California (SC) station, we calculated the resulting set of limiting external conditions: the maximal external dissolved inorganic carbon concentration $\left[\sum \mathrm{CO}_{2}\right]_{\mathrm{f}}^{\max }$, and the minimal free stream, total scale $\left.\mathrm{pH} \mathrm{pH}\right|_{\mathrm{f}} ^{\min }$ (Fig. 6, black lines). The blue lines in Fig. 6 are present-day ambient conditions for comparison, extracted from the Goyet et al. (2000) climatology. It can be seen that present-day ambient conditions are far away from the calculated limit conditions. However, crudely assumed future conditions (i.e., a tripling of $p \mathrm{CO}_{2}$ in the whole water column by appropriate theoretical addition of dissolved inorganic carbon; red lines in Fig. 6), show that there is a region of about $700 \mathrm{~m}$ in depth at this station, where diffusive $\mathrm{CO}_{2}$ export across the DBL could become close to limiting in the future for the given scenario.

\subsection{Is diffusive DBL transport of $\mathrm{CO}_{2}$ or of $\mathrm{O}_{2}$ more limiting?}

While, for completeness, $R P_{\mathrm{CO} 2}$ and $S P_{\mathrm{O}_{2}}$ profiles are given and compared in Appendix $\mathrm{B}$, the better quantity pair to compare DBL transport limitations between $\mathrm{O}_{2}$ and $\mathrm{CO}_{2}$, is the pair $\mathrm{E}_{\max }^{\mathrm{O}_{2}}$ (called $\mathrm{E}_{\max }$ in Hofmann et al., 2012, Eq. 9, Sects. 3.2. and 4.2., Table 2 and Fig. 3) and $\mathrm{E}_{\max }^{\mathrm{CO}_{2}}$, as both quantities similarly depend on the DBL thickness. Figure 7

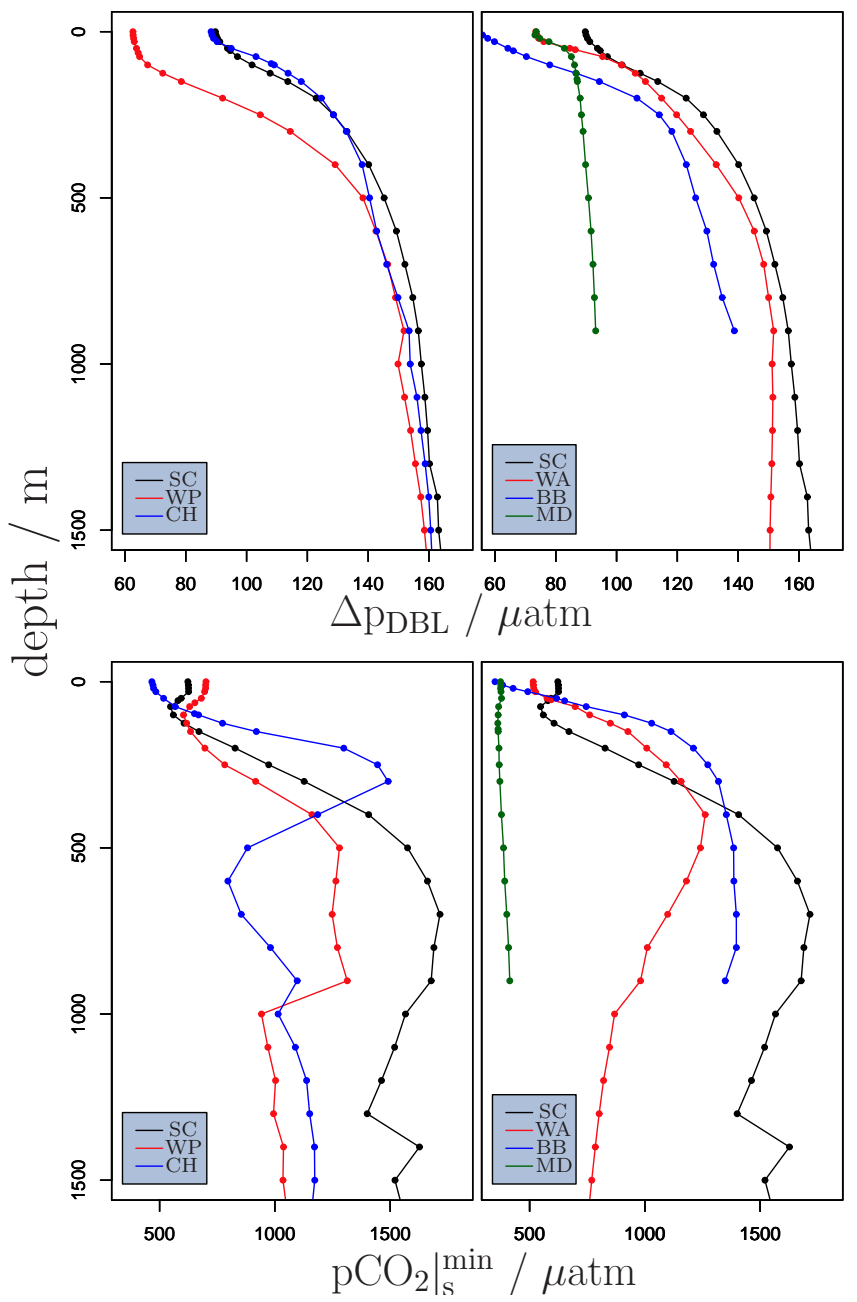

Fig. 5. Example depth profiles of the derived diffusive $\mathrm{CO}_{2}$ export limitation quantities based on a given metabolic rate $E^{\mathrm{O}_{2}}=20 \times 10^{-7} \mu \mathrm{mol} \mathrm{s}{ }^{-1} \mathrm{~cm}^{-2}$. Top panel: $\Delta p_{\text {DBL }}$ (the minimal $\mathrm{CO}_{2}$ partial pressure differential across the DBL required to sustain a given metabolic rate). Bottom panel: $\left.p \mathrm{CO}_{2}\right|_{\mathrm{s}} ^{\mathrm{min}}$ (the minimal $\mathrm{CO}_{2}$ partial pressure in molecular contact with a gas exchange surface that sustains a given metabolic rate under given external oceanic conditions). Oceanographical data are taken from Goyet et al. (2000) and limited to shallower depths when discontinuities occurred deeper (SC: Southern California $\left(120.5^{\circ} \mathrm{W}\right.$, $\left.29.50^{\circ} \mathrm{N}\right)$; $\mathrm{CH}$ : Chile $\left(75.5^{\circ} \mathrm{W}, 33.5^{\circ} \mathrm{S}\right)$; WP: Western Pacific $\left(126.5^{\circ} \mathrm{E}, 11.5^{\circ} \mathrm{N}\right)$, WA: Western Africa $\left(6.5^{\circ} \mathrm{E}, 15.5^{\circ} \mathrm{S}\right)$, MD: Mediterranean $\left(18.5^{\circ} \mathrm{E}, 35.5^{\circ} \mathrm{N}\right)$; BB: Bay of Bengal $\left(87.5^{\circ} \mathrm{E}\right.$, $\left.18.5^{\circ} \mathrm{N}\right)$ ).

compares $\mathrm{E}_{\max }^{\mathrm{O}_{2}}$ and $\mathrm{E}_{\max }^{\mathrm{CO}_{2}}$ profiles for the Southern California station (SC) calculated with different free stream water velocities $u_{100}$. Even comparing $\mathrm{E}_{\max }^{\mathrm{O}_{2}}$ values calculated with $u_{100}=6 \mathrm{~cm} \mathrm{~s}^{-1}$ (orange line), to $\mathrm{E}_{\max }^{\mathrm{CO}_{2}}$ values calculated with $u_{100}=2 \mathrm{~cm} \mathrm{~s}^{-1}$ (blue line), which artificially favours $\mathrm{CO}_{2}$ limitation, shows a strong dominance of diffusive DBL oxygen uptake limitation over diffusive DBL carbon dioxide export limitation. Comparing present-day $\mathrm{E}_{\max }^{\mathrm{O}_{2}}$ values 


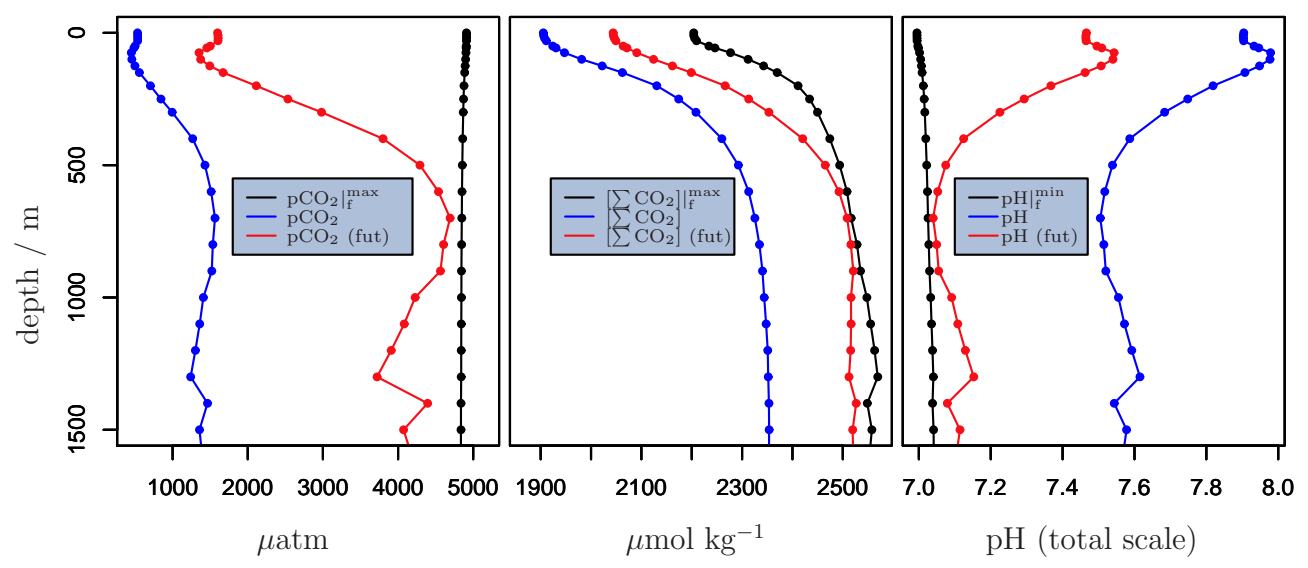

Fig. 6. Example depth profiles for the Southern California example station (SC, $\left.120.5^{\circ} \mathrm{W}, 29.50^{\circ} \mathrm{N}\right)$ of limiting external conditions calculated based on derived diffusive $\mathrm{CO}_{2}$ export limitation quantities assuming a given metabolic rate $E^{\mathrm{O}_{2}}=20 \times 10^{-7} \mu \mathrm{mol} \mathrm{s}^{-1} \mathrm{~cm}^{-2}$ and a given maximal $\mathrm{pCO}_{2}$ in molecular contact with the gas exchange surface $\left.p \mathrm{CO}_{2}\right|_{\mathrm{s}} ^{\max }=5000 \mu \mathrm{atm}$. Left panel: $\left.p \mathrm{CO}_{2}\right|_{\mathrm{f}} ^{\max }\left(\right.$ the maximal $\mathrm{CO}_{2}$ partial pressure in the external bulk free stream that sustains a given metabolic rate; black line), compared to present-day ambient $p \mathrm{CO}_{2}$ values (blue line) and assumed "future" $p \mathrm{CO}_{2}$ values (red line, a tripled $p \mathrm{CO}_{2}$ in the whole water column). Center panel: $\left.\left[\sum \mathrm{CO}_{2}\right]\right|_{\mathrm{f}} ^{\max }$ (the maximal dissolved inorganic carbon concentration, as calculated from $\left.p \mathrm{CO}_{2}\right|_{\mathrm{f}} ^{\max }$, sustaining a given metabolic rate; black line) compared to present-day $\left[\sum \mathrm{CO}_{2}\right]$ values (blue line) and assumed "future" [ $\left.\sum \mathrm{CO}_{2}\right]$ values (red line; consistent with a tripled $p \mathrm{CO}_{2}$ in the whole water column). Right panel: $\left.\mathrm{pH}\right|_{\mathrm{f}} ^{\min }$ (the minimal external total scale $\mathrm{pH}$, as calculated from $\left.p \mathrm{CO}_{2}\right|_{\mathrm{f}} ^{\max }$, sustaining a given metabolic rate; black line), compared to present-day total scale $\mathrm{pH}$ values (blue line), and assumed 'future" $\mathrm{pH}$ values (red line; consistent with a tripled $p \mathrm{CO}_{2}$ in the whole water column). Oceanographical data are taken from Goyet et al. (2000).

with $\mathrm{E}_{\max }^{\mathrm{CO}_{2}}$ calculated with assumed future conditions (i.e., a tripled $p \mathrm{CO}_{2}$ throughout the whole water column, red line), still reveals a dominance of diffusive oxygen limitation over diffusive carbon dioxide export limitation. This is without assuming any future decline in oceanic oxygenation, which would decrease $\mathrm{E}_{\max }^{\mathrm{O}_{2}}$ values even further and would, thus, amplify the dominance of oxygen limitation over carbon dioxide limitation.

Additionally important to note is that the value for $\left.p \mathrm{CO}_{2}\right|_{\mathrm{s}}$ used here is deliberately chosen to be comparatively low, i.e., only the most sensitive organisms show reactions in Caldeira et al. (2005), so that the defined $\mathrm{CO}_{2}$ limiting quantities likely overestimate the $\mathrm{CO}_{2}$ removal limitation. So when compared to the equivalent oxygen supply limitation quantities, highest conceivable $\mathrm{CO}_{2}$ export limitations are considered. Still, diffusive oxygen uptake limitation seems to be dominant, due to the chemical enhancement of the diffusive $\mathrm{CO}_{2}$ export.

\section{Conclusions and outlook}

The ocean is now undergoing simultaneous warming, loss of $\mathrm{CO}_{2}$ and rising $\mathrm{CO}_{2}$ levels. The impact of changes in each of these properties draws intense scientific scrutiny, but ways in which the ensemble effect can be estimated are few. In a first attempt to address the combined impacts Brewer and Peltzer (2009) defined a "respiration index" which linked the ratios of $p \mathrm{O}_{2}$ to $p \mathrm{CO}_{2}$ via the simple form of the Gibbs' free energy equation. This paper, by converting traditional prop- erties such as a simple mass values for $\left[\mathrm{O}_{2}\right]$ into the partial pressures that can accommodate changing temperature and correctly represent the driving force for respiration, is an attempt to assess the relative hospitability of certain ocean regions to support aerobic respiration (e.g. Mayol et al., 2010).

Our findings here, and in the oxygen companion paper, that it is energetically easier to transport $\mathrm{CO}_{2}$ away from an organism due to the chemical enhancement term than to bring $\mathrm{O}_{2}$ towards it which requires physical changes in diffusive boundary layer thickness, suggests a route towards an improved function. In this function, estimating only physical processes originating in the external ocean, declines in $p \mathrm{O}_{2}$ would be given more weight than increases in $p \mathrm{CO}_{2}$.

Although neither impact is positive for marine life, considering only diffusive limitation effects, global warming/declining $\mathrm{O}_{2}$ is most likely a greater threat to most oceanic life than is oceanic uptake of anthropogenic $\mathrm{CO}_{2}$. However, there might be further respiratory effects of $\mathrm{CO}_{2}$ input and acidification that are not considered here: such as oxygen transport mechanisms in animals are impacted by an elevated proton concentration (e.g. Seibel and Walsh, 2003) and the decrease of the free energy yield of the respiration reaction (Brewer and Peltzer, 2009).

Of course, as already widely studied and well known, ocean acidification due to anthropogenic $\mathrm{CO}_{2}$ uptake of the oceans results in a decrease in the carbonate ion concentration with negative effects on biogenic calcification. Animals will have to expend energy in an effort to reduce the loss of carbonate shell protection. This means $\mathrm{O}_{2}$ dependent 


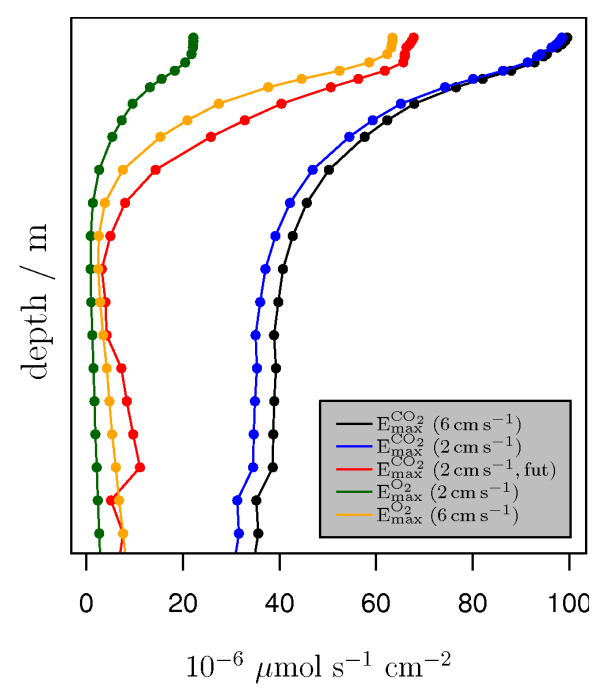

Fig. 7. Example depth profiles for the Southern California example station $\left(\mathrm{SC}, 120.5^{\circ} \mathrm{W}, 29.50^{\circ} \mathrm{N}\right.$ ) of diffusive carbon dioxide export limitation quantities as defined here, compared to equivalent diffusive oxygen uptake limitation quantities defined in the companion paper Hofmann et al. (2012): $\mathrm{E}_{\max }^{\mathrm{CO}_{2}}$ (the maximal $\mathrm{CO}_{2}$ diffusion limited metabolic rate), calculated with various given values for the fluid flow velocity $u_{100}$, and current and future $p \mathrm{CO}_{2}$ conditions, compared to $\mathrm{E}_{\max }^{\mathrm{O}_{2}}$ (the maximal $\mathrm{O}_{2}$ diffusion limited metabolic rate, calculated according to Hofmann et al. (2012) with various $u_{100}$ values and current oxygenation conditions). Oceanographical data for $\mathrm{CO}_{2}$ are taken from the Goyet et al. (2000) climatology. Oceanographical data for $\mathrm{O}_{2}$ are taken from the Garcia et al. (2010) oxygen climatology.

processes will have to be increased, in principle favouring non-calcifying organisms in high $\mathrm{CO}_{2}$ low $\mathrm{O}_{2}$ regions and, thus, establishing a more direct linkage between $\mathrm{O}_{2}$ and $\mathrm{CO}_{2}$ in the ocean.

\section{Appendix A}

Details on the Sensitivity of $R P_{\mathrm{CO}_{2}}$ and $\mathrm{E}_{\max }^{\mathrm{CO}_{2}}$ with respect to $u_{100}$ and $\left.p \mathrm{CO}_{2}\right|_{\mathrm{s}} ^{\max }$

\section{A1 Oceanic $\mathrm{CO}_{2}$ removal potential: $\boldsymbol{R} \boldsymbol{P}_{\mathrm{CO}_{2}}$}

The left panel in the upper row of Fig. 2 shows that the EF dependency on $u_{100}$ (the relative current velocity over gas exchange tissues, a combination of ambient current flow and animal activity like swimming or pumping) is dominated by the dependency of the DBL thickness $L^{\mathrm{CO}_{2}}$ on $u_{100}$ (see Table 2 and the companion paper Hofmann et al. (2012) (Sects. 4.2. and 4.4., and Fig. 4) for details). Since $R P_{\mathrm{CO}_{2}}$ depends linearly on EF (cf. Eq. 16), the EF dependency on $u_{100}$ exactly mirrors the $R P_{\mathrm{CO}_{2}}$ dependency on $u_{100}$ (not shown).

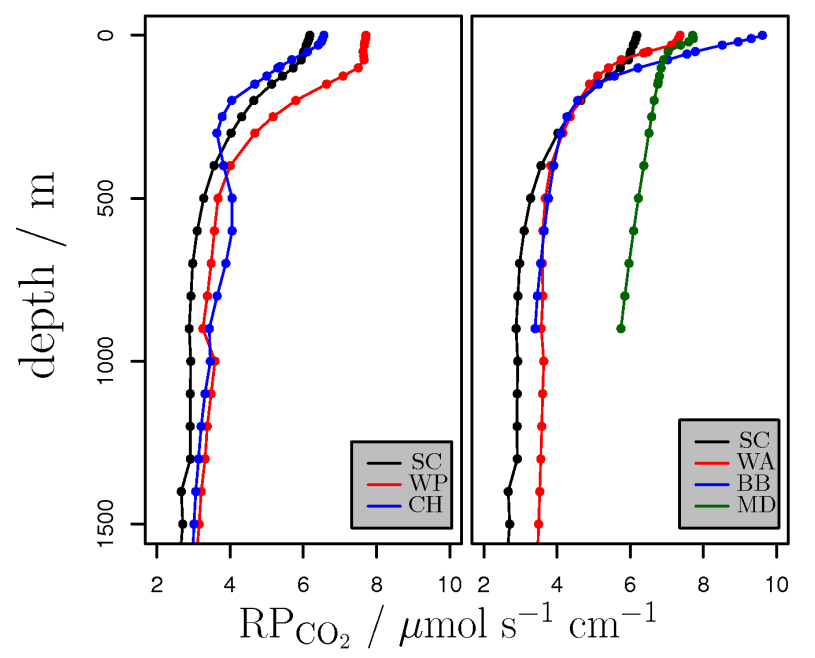

Fig. 8. Example depth profiles of the derived diffusive $\mathrm{CO}_{2}$ export limitation quantity $R P_{\mathrm{CO}_{2}}$ (the oceanic $\mathrm{CO}_{2}$ removal potential), calculated using the chemical enhancement factor $\mathrm{EF}$ according to Eq. (10) with $u_{100}=6 \mathrm{~cm} \mathrm{~s}^{-} 1 .\left.p \mathrm{CO}_{2}\right|_{\mathrm{s}} ^{\max }=5000 \mu \mathrm{atm}$. Oceanographical data are taken from Goyet et al. (2000) and limited to shallower depths when discontinuities occurred deeper (SC: Southern California $\left(120.5^{\circ} \mathrm{W}, 29.50^{\circ} \mathrm{N}\right)$; $\mathrm{CH}$ : Chile $\left(75.5^{\circ} \mathrm{W}\right.$, $\left.33.5^{\circ} \mathrm{S}\right)$; WP: Western Pacific $\left(126.5^{\circ} \mathrm{E}, 11.5^{\circ} \mathrm{N}\right)$, WA: Western Africa $\left(6.5^{\circ} \mathrm{E}, 15.5^{\circ} \mathrm{S}\right), \mathrm{MD}$ : Mediterranean $\left(18.5^{\circ} \mathrm{E}, 35.5^{\circ} \mathrm{N}\right)$; $\mathrm{BB}$ : Bay of Bengal $\left(87.5^{\circ} \mathrm{E}, 18.5^{\circ} \mathrm{N}\right)$ ).

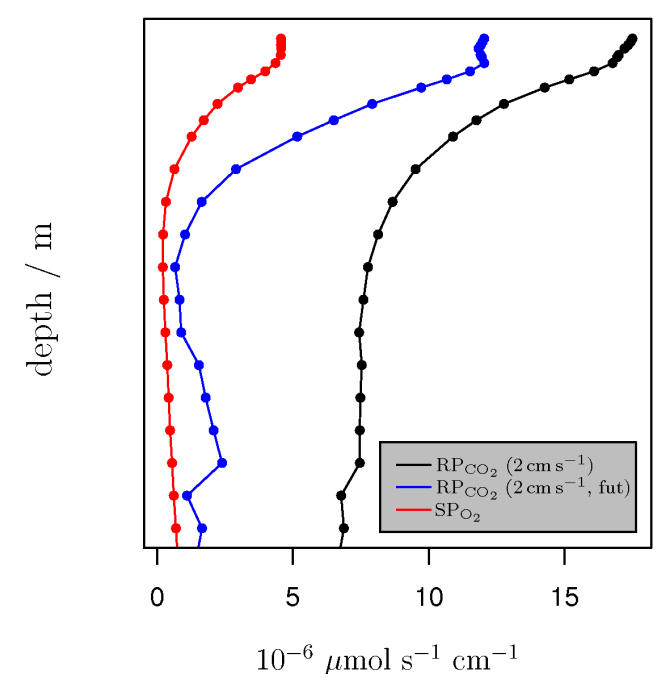

Fig. 9. Example depth profiles for the Southern California example station $\left(\mathrm{SC}, 120.5^{\circ} \mathrm{W}, 29.50^{\circ} \mathrm{N}\right.$ ) of diffusive carbon dioxide export limitation quantities as defined here, compared to equivalent diffusive oxygen uptake limitation quantities defined in the companion paper Hofmann et al. (2012): $R P_{\mathrm{CO}_{2}}$ (the oceanic $\mathrm{CO}_{2}$ removal potential) calculated with $u_{100}=2 \mathrm{~cm} \mathrm{~s}^{-1}$ and current ambient $p \mathrm{CO}_{2}$ values (black line) and assumed "future" tripled $p \mathrm{CO}_{2}$ values (blue line), compared to $S P_{\mathrm{O}_{2}}$ (the oceanic oxygen supply potential, calculated according to Hofmann et al., 2012). 
$\mathrm{EF}$, a key variable determining $R P_{\mathrm{CO}_{2}}$, increases with increasing temperature, roughly two-fold for a temperature increase from $1{ }^{\circ} \mathrm{C}$ to $25^{\circ} \mathrm{C}$ (top left panel of Fig. 2). The general dependency of $\mathrm{EF}$ on $u_{100}$ is not affected by temperature.

The central panel in the top row of Fig. 2 shows that $R P_{\mathrm{CO}_{2}}$ increases by about an order of magnitude in the $u_{100}$ range sampled, with the largest steps being exhibited for small $u_{100}$, which is consistent with the steep part of the curve of the EF dependency on $u_{100}$ for $u_{100}$ values below approximately $3 \mathrm{~cm} \mathrm{~s}^{-1}$.

The hypothetical case of no $\mathrm{CO}_{2}$ reactivity $(\mathrm{EF}=1)$ is included here, purely to show the importance of $\mathrm{CO}_{2}$ reactivity by comparison to the plots with realistic EF. With $\mathrm{EF}=1$ there would be no dependency of $R P_{\mathrm{CO}_{2}}$ on $u_{100}$, but this hypothetical case is, as was to be expected, equivalent to very large values of $u_{100}$. Consistently, the lowest values for $R P_{\mathrm{CO}_{2}}$ are obtained for the hypothetical $\mathrm{EF}=1$ case.

The right panel in the top row of Fig. 2 illustrates the linear dependency of $R P_{\mathrm{CO}_{2}}$ on the $\mathrm{CO}_{2}$ partial pressure limit value in molecular contact with the organism $\left.\left(\left.p \mathrm{CO}_{2}\right|_{\mathrm{s}}=\right) p \mathrm{CO}_{2}\right|_{\mathrm{s}} ^{\max } \cdot R P_{\mathrm{CO}_{2}}$ values increase from about 2 $10^{-6} \mu \mathrm{mol} \mathrm{s}^{-1}$ to about $20 \times 10^{-6} \mu \mathrm{mol} \mathrm{s}{ }^{-1}$, when $p \mathrm{CO}_{\left.2\right|_{\mathrm{s}} ^{\max }}$ increases from $2000 \mu \mathrm{atm}$ to $20000 \mu \mathrm{atm}$.

\section{A2 Maximal DBL diffusion limited $\mathrm{CO}_{2}$ export flux: $\mathbf{E}_{\text {max }}^{\mathrm{CO}_{2}}$}

The left panel in the bottom row of Fig. 2 shows that $\mathrm{E}_{\max }^{\mathrm{CO}_{2}}$ increases steeply with increasing $u_{100}$, once $u_{100}$ has values above approximately $3 \mathrm{~cm} \mathrm{~s}^{-1}$. Below a free stream velocity of $3 \mathrm{~cm} \mathrm{~s}^{-1}, \mathrm{E}_{\max }^{\mathrm{CO}_{2}}$ is virtually independent of $u_{100}$. For $u_{100}$ values larger than $5 \mathrm{~cm} \mathrm{~s}^{-1}$ the relation is almost linear. The overall positive correlation of $\mathrm{E}_{\max }^{\mathrm{CO}_{2}}$ with $u_{100}$ shows that the effect of increasing flow decreasing the distance for diffusion ( $L^{\mathrm{CO}_{2}}$ decreases with increasing $u_{100}$, which increases $\mathrm{E}_{\max }^{\mathrm{CO}_{2}}$ ) dominates over the effect that this decreased distance allows for less time for the $\mathrm{CO}_{2}$ system to enhance the diffusive flux via chemical reactions (EF decreases with increasing $u_{100}$, which decreases $\mathrm{E}_{\max }^{\mathrm{CO}_{2}}$ ).

$\mathrm{E}_{\max }^{\mathrm{CO}_{2}}$ increases with increasing temperature, also about two-fold for a temperature increase from $1{ }^{\circ} \mathrm{C}$ to $25^{\circ} \mathrm{C}$ (bottom left panel of Fig. 2). It can be seen that the dependency of $\mathrm{E}_{\max }^{\mathrm{CO}_{2}}$ on $u_{100}$ is less pronounced for higher temperatures.

In the purely hypothetical case of $\mathrm{EF}=1$ (only included for comparison), one assumes an effect of $u_{100}$ on $L^{\mathrm{CO}_{2}}$, i.e., decreasing the distance for diffusion with increasing flow velocity, but the effect of chemical enhancement in a thick DBL is neglected. Therefore, the $\mathrm{EF}=1$ case here shows the lowest values for $\mathrm{E}_{\max }^{\mathrm{CO}_{2}}$ although for the calculation of $L^{\mathrm{CO}_{2}}$ an intermediate value of $6 \mathrm{~cm} \mathrm{~s}^{-1}$ is used for $u_{100}$. This clearly illustrates the importance of the inclusion of $\mathrm{CO}_{2}$ reactivity, i.e., realistic $\mathrm{EF}$ values, for estimating values for $\mathrm{E}_{\max }^{\mathrm{CO}_{2}}$.

\section{A3 Comparing $\boldsymbol{R} \boldsymbol{P}_{\mathrm{CO}_{2}}$ with $\mathrm{E}_{\max }^{\mathrm{CO}_{2}}$}

$R P_{\mathrm{CO}_{2}}$ depends on EF which decreases with increasing $u_{100}$, i.e., in a thinner boundary layer, there is less time for the $\mathrm{CO}_{2}$ acid-base system to convert $\mathrm{CO}_{2}$ to carbonate and bicarbonate and, thus, effectively remove $\mathrm{CO}_{2}$ itself which enhances diffusion. However, $R P_{\mathrm{CO}_{2}}$ does not incorporate the fact that with a thinner boundary layer, there is a shorter way for the $\mathrm{CO}_{2}$ to diffuse through, since the DBL thickness $L^{\mathrm{CO}_{2}}$ is removed from the definition to be consistent with the oxygen quantity $S P_{\mathrm{O}_{2}}$ in the companion paper. The quantity $\mathrm{E}_{\max }^{\mathrm{CO}_{2}}$, however, does include this effect.

Comparing the central panels in upper and bottom rows of Fig. 2 illustrates the difference in DBL thickness $L^{\mathrm{CO}_{2}}$ (i.e., $\left.u_{100}\right)$ dependency of $R P_{\mathrm{CO}_{2}}$ and $\mathrm{E}_{\mathrm{max}}^{\mathrm{CO}_{2}}$. While $R P_{\mathrm{CO}_{2}}$ shows a strong negative correlation with $u_{100}$ (central panel, top row Fig. 2), $\mathrm{E}_{\max }^{\mathrm{CO}_{2}}$, exhibits a moderate positive correlation with $u_{100}$. As already mentioned above, the effect of less distance for diffusion with increasing $u_{100}$ outweighs the effect of less time for chemical enhancement of the flux with increasing $u_{100}$. However, due to the combination of those two counteracting effects, the net dependency of $\mathrm{E}_{\max }^{\mathrm{CO}_{2}}$ on $u_{100}$ is much less pronounced than the dependency of $R P_{\mathrm{CO}_{2}}$ on $u_{100}$. In the central panel of the bottom row of Fig. 2, it can also clearly be seen that the dependency of $\mathrm{E}_{\max }^{\mathrm{CO}_{2}}$ on $u_{100}$ is less pronounced at shallower depths with higher temperatures and $\mathrm{pH}$ values than at deeper depths with colder temperatures and lower $\mathrm{pH}$ values.

The right panel in the bottom row of Fig. 2 shows that the dependency on $\left.p \mathrm{CO}_{2}\right|_{\mathrm{s}} ^{\max }$ is similar for $\mathrm{E}_{\max }^{\mathrm{CO}_{2}}$ and $R P_{\mathrm{CO}_{2}}$.

\section{Appendix B}

\section{$R P_{\mathrm{CO}_{2}}$ depth profiles}

For comparison to the oceanic oxygen supply potential $S P_{\mathrm{O}_{2}}$ from companion paper Hofmann et al. (2012) (Fig. 2), depth profiles of $R P_{\mathrm{CO}_{2}}$ for all stations are given in Fig. 8 .

Fig. 9 compares $S P_{\mathrm{O}_{2}}$ (red line) and $R P_{\mathrm{CO}_{2}}$ profiles for the Southern California station (SC), calculated with a fluid flow velocity of $2 \mathrm{~cm} \mathrm{~s}^{-1}$ (black line). $S P_{\mathrm{O}_{2}}$ values are considerably lower than $R P_{\mathrm{CO}_{2}}$ values throughout the whole water column, suggesting that diffusive limitation of oxygen uptake is dominant over diffusive limitation of respiratory carbon dioxide export. Comparing present-day $\mathrm{SP}_{\mathrm{O}_{2}}$ values with $R P_{\mathrm{CO}_{2}}$ calculated with assumed future conditions (i.e., a tripled $p \mathrm{CO}_{2}$ throughout the whole water column, blue line), still reveals a dominance of diffusive oxygen limitation over diffusive carbon dioxide export limitation. And this is without assuming any decline in oceanic oxygenation, which would decrease $S P_{\mathrm{O}_{2}}$ values even further and would, thus, amplify the dominance of oxygen limitation over carbon dioxide limitation. It must be noted, however, that, although both quantities are defined as equivalent as possible, $R P_{\mathrm{CO} 2}$ 
still depends on the free stream water velocity $u_{100}$ via the enhancement factor EF, which makes $S P_{\mathrm{O}_{2}}$ and $R P_{\mathrm{CO} 2}$ none optimal quantities when comparing diffusive oxygen uptake limitation to diffusive carbon dioxide export limitation.

Acknowledgements. This work was supported by a grant to the Monterey Bay Aquarium Research Institute from the David and Lucile Packard Foundation.

Edited by: J. Middelburg

\section{References}

Allen, M. R., Frame, D. J., Huntingford, C., Jones, C. D., Lowe, J. A., Meinshausen, M., and Meinshausen, N.: Warming caused by cumulative carbon emissions towards the trillionth tonne, $\mathrm{Na}-$ ture, 458, 1163-1166, doi:10.1038/nature08019, 2009.

Allison, I., Bindoff, N. L., Bindschadler, R. A., Cox, P. M., de Noblet, N., England, M. H., Francis, J. E., Gruber, N., Haywood, A. M., Karoly, D. J., Kaser, G., Le Quèrè, C., Lenton, T. M., Mann, M. E., McNeil, B. I., Pitman, A. J., Rahmstorf, S., Rignot, E., Schellnhuber, H. J., Schneider, S. H., Sherwood, S. C., Somerville, R. C. J., Steffen, K., Steig, E. J., Visbeck, M., and J., W. A.: The Copenhagen Diagnosis: Updating the world on the Latest Climate Science, The University of New South Wales Climate Change Research Centre (CCRC), Sydney, Australia, 60 pp., 2009.

Archer, D.: Modeling $\mathrm{CO}_{2}$ in the Ocean: a review, in: Scaling of Trace Gas Fluxes between Terrestrial and Aquatic Ecosystems and the Atmosphere, edited by: Bouwman, A. F., vol. 24, 169184, Elsevier Sciences, Amsterdam, 1999.

Archer, D.: Fate of fossil fuel $\mathrm{CO}_{2}$ in geologic time, J. Geophys. Res.-Oc., 110, C09S05, doi:10.1029/2004JC002625, 2005.

Archer, D., Kheshgi, H., and Maier-Reimer, E.: Dynamics of fossil fuel $\mathrm{CO}_{2}$ neutralization by marine $\mathrm{CaCO}_{3}$, Global Biogeochem. Cy., 12, 259-276, 1998.

Archer, D., Eby, M., Brovkin, V., Ridgwell, A., Cao, L., Mikolajewicz, U., Caldeira, K., Matsumoto, K., Munhoven, G., Montenegro, A., and Tokos, K.: Atmospheric Lifetime of Fossil Fuel Carbon Dioxide, Ann. Rev. Earth Planet. Sci., 37, 117-134, doi:10.1146/annurev.earth.031208.100206, 2009.

Biron, P. M., Robson, C., Lapointe, M. F., and Gaskin, S. J.: Comparing different methods of bed shear stress estimates in simple and complex flow fields, Earth Surf. Proc. Land., 29, 1403-1415, doi:10.1002/esp.1111, 2004.

Blackford, J. C. and Gilbert, F. J.: pH variability and $\mathrm{CO}_{2}$ induced acidification in the North Sea, J. Mar. Syst., 64, 229-241, 2007.

Bolin, B.: On the exchange of carbon dioxide between the atmosphere and the sea, Tellus B, 12, 274-281, 1960.

Boudreau, B. P.: A method-of-lines code for carbon and nutrient diagenesis in aquatic sediments, Computers Geosciences, 22, 479496, 1996.

Brewer, P. G.: A Short History of Ocean Acidification Science in the 20th Century, Biogeosciences Discuss, submitted, 2013.

Brewer, P. and Peltzer, E.: Limits to Marine Life, Science, 324, 347348, 2009.
Brewer, P. G., Friederich, G., Peltzer, E. T., and Orr Jr., F. M.: Direct Experiments on the Ocean Disposal of Fossil Fuel $\mathrm{CO}_{2}$, Science, 284, 943-945, doi:10.1126/science.284.5416.943, 1999.

Bryden, H. L.: New polynomials for thermal expansion, adiabatic temperature gradient and potential temperature of sea water, Deep-Sea Res., 20, 401-408, 1973.

Caldeira, K. and Wickett, M. E.: Anthropogenic carbon and ocean pH, Nature, 425, 365-365, 2003.

Caldeira, K. and Wickett, M. E.: Ocean model predictions of chemistry changes from carbon dioxide emissions to the atmosphere and ocean, J. Geophys. Res.-Oc., 110, C09S04,doi:10.1029/2004JC002671, 2005.

Caldeira, K., Akai, M., Brewer, P., Chen, B., Haugan, P., Iwama, T., Johnston, P., Kheshgi, H., Li, Q., Ohsumi, T., Pörtner, H. O., Sabine, C., Shirayama, Y., Thomson, J., Barry, J., and Hansen, L.: Ocean Storage, in: IPCC Special Report on Carbon dioxide Capture and Storage, IPCC, 2005.

Dickson, A. G.: Ph Scales and Proton-Transfer Reactions in Saline Media Such as Sea-Water, Geochimica Et Cosmochimica Acta, 48, 2299-2308, 1984.

Dickson, A. G., Sabine, C., and Christian, J. R.: Guide to best practices for ocean $\mathrm{CO}_{2}$ measurements, PICES Special Publication 3 IOCCP Report No. 8, North Pacific Marine Science Organization, 1-191, 2007.

DOE: Handbook of Methods for the Analysis of the Various Parameters of the Carbon Dioxide System in Sea Water, ORNL/CDIAC-74, 1994.

Emerson, S.: Chemically Enhanced Carbon Di Oxide Gas Exchange In A Eutrophic Lake A General Model, Limnol. Oceanogr., 20, 743-761, 1975.

Enns, T., Scholander, P. F., and Bradstreet, E. D.: Effect of Hydrostatic Pressure on Gases Dissolved in Water, J. Phys. Chem., 69, 389-391, 1965.

Feder, M. E. and Burggren, W. W.: Cutaneous gas exchange in vertebrates: design, patterns, control and implications, Biol. Rev. Camb. Philos. Soc., 60, 1-45, 1985.

Feder, M. E. and Pinder, A. W.: Ventilation And Its Effect On Infinite Pool Exchangers, American Zoologist, 28, 973-984, 1988.

Field, C. B., Barros, V., Stocker, T. F., Dahe, Q., Mach, K. J., Plattner, G. K., Mastrandea, M. D., M., T., and Ebi, K. L.: IPCC workshop on impacts of ocean acidification on marine biology and ecosystems, Bankoku, Okinawa, Japan, Tech. rep., 164 pp., 2011.

Fofonoff, N. P.: Computation of potential temperature of seawater for an arbitrary reference pressure, Deep-Sea Res., 24, 489-491, 1977.

Fofonoff, N. P. and Millard, R. C. J.: Algorithms for computation of fundamental properties of seawater, UNESCO Techn. Papers Mar. Sci., 44, 55 pp., 1983.

Garcia, H. E., Locarnini, R. A., Boyer, T. P., Antonov, J. I., Baranova, O. K., Zweng, M. M., and Johnson, D. R.: World Ocean Atlas 2009, Volume 3: Dissolved Oxygen, Apparent Oxygen Utilization, and Oxygen Saturation., NOAA Atlas NESDIS 70, edited by: Levitus, S., US Government Printing Office, Washington, DC, 344 pp., 2010.

Gattuso, J. P., Frankignoulle, M., Bourge, I., Romaine, S., and Buddemeier, R. W.: Effect of calcium carbonate saturation of seawater on coral calcification, Glob. Planet. Change, 18, 37-46, doi:10.1016/S0921-8181(98)00035-6, 1998. 
Goyet, C., Healy, R. J., and Ryan, J. P.: Global distribution of total inorganic carbon and total alkalinity below the deepest winter mixed layer depths, ORNL/CDIAC-127, NDP-076. Carbon Dioxide Information Analysis Center, Oak Ridge National Laboratory, US Department of Energy, Oak Ridge, Tennessee, 40 pp., 2000.

Haugan, P. M.: On the production and use of scientific knowledge about ocean sequestration, in: Greenhouse Gas Control Technologies, Vol. 1., 719-724. Proceedings of the 6th International Conference on Greenhouse Gas Control Technolgies., edited by: Gale, J. and Kaya, Y., Elsevier, Kyoto, Japan, 710-724, 2003.

Hickey, B., Baker, E., and Kachel, N.: Suspended particle movement in and around Quinault submarine canyon, Mar. Geol., 71, 35-83, doi:10.1016/0025-3227(86)90032-0, 1986.

Hickey, B. M., Dobbins, E. L., and Allen, S. E.: Local and remote forcing of currents and temperature in the central Southern California Bight, J. Geophys. Res.-Oc., 108, 3081, doi:10.1029/2000JC00313, 2003.

Hofmann, A. F., Meysman, F. J. R., Soetaert, K., and Middelburg, J. J.: A step-by-step procedure for $\mathrm{pH}$ model construction in aquatic systems, Biogeosciences, 5, 227-251, doi:10.5194/bg-5227-2008, 2008.

Hofmann, A. F., Soetaert, K., Middelburg, J. J., and Meysman, F. J. R.: AquaEnv : An Aquatic Acid-Base Modelling Environment in R, Aq. Geochem., 16, 507-546, 2010.

Hofmann, A. F., Peltzer, E. T., and Brewer, P. G.: Kinetic bottlenecks to chemical exchange rates for deep-sea animals Part 1: Oxygen, Biogeosciences Discuss., 9, 13817-13856, doi:10.5194/bgd-9-13817-2012, 2012.

IPCC: Climate Change 2007: Synthesis Report. Contributions of Working Groups I, II, and III to the Fourth Assessment Report of the Intergovernmental Panel on Climate Change, Tech. rep., Geneva, Switzerland, 2007.

Kita, J. and Ohsumi, T.: Perspectives on Biological Research for Biological Research for $\mathrm{CO}_{2}$, Ocean Sequestration, J. Oceanogr., 60, 695-703, doi:10.1007/s10872-004-5762-1, 2004.

Koertzinger, A.: Determination of carbon dioxide partial pressure $\left(p\left(\mathrm{CO}_{2}\right)\right)$, in: Methods of Seawater Analysis, edited by: Grasshoff, K., Kremling, K., and Erhardt, M., Wiley-VCH, Weinheim, 149-158, 1999.

Marchetti, C.: On geoengineering and the $\mathrm{CO}_{2}$ problem, Clim. Change, 1, 59-68, doi:10.1007/BF00162777, 1977.

Mayol, E., Ruiz-Halpern, S., Duarte, C. M., Castilla, J. C., and Pelegrí, J. L.: Coupled $\mathrm{CO}_{2}$ and $\mathrm{O}_{2}$-driven compromises to marine life in summer along the Chilean sector of the Humboldt Current System, Biogeosciences, 9, 1183-1194, doi:10.5194/bg9-1183-2012, 2012.

Meehl, G. A., Stocker, T. F., Collins, W. D., Friedlingstein, P., Gaye, A. T., Gregory, J. M., Kitoh, A., Knutti, R., Murphy, J. M., Noda, A., Raper, S. C. B., Watterson, I. G., Weaver, A. J., and Zhao, Z.C.: Global Climate Projections, in: Climate Change 2007: The Physical Science Basis, Contribution of Working Group I to the Fourth Assessment Report of the Intergovernmental Panel on Climate Change, edited by: Solomon, S., Qin, D., Manning, M., Chen, Z., Marquis, M., Averyt, K. B., Tignor, M., and Miller, H. L., Cambridge University Press, Cambridge, UK and New York, NY, USA, 747-845, 2007.

Millero, F. J.: Thermodynamics of the Carbon-Dioxide System in the Oceans, Geochim. Cosmochim. Ac., 59, 661-677, 1995.
Millero, F. J. and Poisson, A.: International One-Atmosphere Equation of State of Seawater, Deep-Sea Res. Pt. 1, 28, 625-629, 1981.

Millero, F. J., Graham, T. B., Huang, F., Bustos-Serrano, H., and Pierrot, D.: Dissociation constants of carbonic acid in seawater as a function of salinity and temperature, Mar. Chem., 100, 8094, 2006.

Orr, J. C., Fabry, V. J., Aumont, O., Bopp, L., Doney, S. C., Feely, R. A., Gnanadesikan, A., Gruber, N., Ishida, A., Joos, F., Key, R. M., Lindsay, K., Maier-Reimer, E., Matear, R., Monfray, P., Mouchet, A., Najjar, R. G., Plattner, G. K., Rodgers, K. B., Sabine, C. L., Sarmiento, J. L., Schlitzer, R., Slater, R. D., Totterdell, I. J., Weirig, M. F., Yamanaka, Y., and Yool, A.: Anthropogenic ocean acidification over the twenty-first century and its impact on calcifying organisms, Nature, 437, 681-686, 2005.

Patterson, M. R. and Sebens, K. P.: Forced-Convection Modulates Gas-Exchange in Cnidarians, Proc. Natl. Acad. Sci. USA, 86, 8833-8836, doi:doi:10.1073/pnas.86.22.8833, 1989.

Peña, M. A., Katsev, S., Oguz, T., and Gilbert, D.: Modeling dissolved oxygen dynamics and hypoxia, Biogeosciences, 7, 933957, doi:10.5194/bg-7-933-2010, 2010.

Perry, S. F., Braun, M. H., Genz, J., Vulesevic, B., Taylor, J., Grosell, M., and Gilmour, K. M.: Acid-base regulation in the plainfin midshipman (Porichthys notatus): an aglomerular marine teleost, J. Comp. Physiol. B, 180, 1213-1225, 2010.

Pinczewski, W. V. and Sideman, S.: A model for mass (heat) transfer in turbulent tube flow. Moderate and high Schmidt (Prandtl) numbers, Chem. Engin. Sci., 29, 1969-1976, doi:10.1016/00092509(74)85016-5, 1974.

Pinder, A. W. and Feder, M. E.: Effect of Boundary Layers on Cutaneous Gas Exchange, J. Exp. Biol., 154, 67-80, 1990.

Poertner, H. O., Langenbuch, M., and Michaelidis, B.: Synergistic effects of temperature extremes, hypoxia, and increases in $\mathrm{CO}_{2}$ on marine animals: From Earth history to global change, J. Geophys. Res.-Oc., 110, C09S10, doi:10.1029/2004JC002561, 2005.

Quinn, J. A. and Otto, N. C.: Carbon Dioxide Exchange at the AirSea Interface: Flux Augmentation by Chemical Reaction, J. Geophys. Res., 76, 1539-1549, 1971.

Rabalais, N. N., Díaz, R. J., Levin, L. A., Turner, R. E., Gilbert, D., and Zhang, J.: Dynamics and distribution of natural and humancaused hypoxia, Biogeosciences, 7, 585-619, doi:10.5194/bg-7585-2010, 2010.

Royal Society: Ocean Acidification Due to Increasing Atmospheric Carbon Doxide, Policy Document 12/05, The Royal Society, London, UK, 2005.

Sabine, C. L., Feely, R. A., Gruber, N., Key, R. M., Lee, K., Bullister, J. L., Wanninkhof, R., Wong, C. S., Wallace, D. W. R., Tilbrook, B., Millero, F. J., Peng, T. H., Kozyr, A., Ono, T., and Rios, A. F.: The oceanic sink for anthropogenic $\mathrm{CO}_{2}$, Science, 305, 367-371, 2004.

Santschi, P. H., Anderson, R. F., Fleisher, M. Q., and Bowles, W.: Measurements of Diffusive Sublayer Thicknesses in the Ocean by Alabaster Dissolution, and Their Implications for the Measurements of Benthic Fluxes, J. Geophys. Res., 96, 1064110657, 1991.

Sarmiento, J. L. and Toggweiler, J. R.: A New Model for the Role of the Oceans in Determining Atmospheric $p \mathrm{CO}_{2}$, Nature, 308, 621-624, 1984. 
Sarmiento, J. L., Le Quèrè, C., and Pacala, S. W.: Limiting future atmospheric carbon dioxide, Global Biogeochem. Cy., 9, 121137, doi:10.1029/94GB01779, 1995.

Seibel, B. A. and Walsh, P. J.: Potential Impacts of $\mathrm{CO}_{2}$ Injection on Deep-Sea Biota, Science, 294, 319-320, doi:10.1126/science.1065301, 2001.

Seibel, B. A. and Walsh, P. J.: Biological impacts of deep-sea carbon dioxide injection inferred from indices of physiological performance, J Experiment Biol, 206, 641-650, 2003.

Shaffer, G., Olsen, S. M., and Pedersen, J. O. P.: Long-term ocean oxygen depletion in response to carbon dioxide emissions from fossil fuels, Nature Geosci., 2, 105-109, doi:10.1038/NGEO420, 2009.

Shashar, N., Cohen, Y., and Loya, Y.: Extreme Diel Fluctuations Of Oxygen In Diffusive Boundary-Layers Surrounding Stony Corals, Biol. Bull., 185, 455-461, 1993.

Shaw, D. A. and Hanratty, T. J.: Turbulent mass transfer rates to a wall for large Schmidt numbers, AIChE Journal, 23, 28-37, doi:10.1002/aic.690230106, 1977.

Siegenthaler, U. and Wenk, T.: Rapid Atmospheric $\mathrm{CO}_{2}$ Variations and Ocean Circulation, Nature, 308, 624-626, 1984.

Soetaert, K., Petzoldt, T., and Meysman, F.: marelac: Tools for Aquatic Sciences, R package version 2.1, 2010.
Sternberg, R. W.: Friction factors in tidal channels with differing bed roughness, Marine Geology, 6, 243-260, doi:10.1016/00253227(68)90033-9, 1968.

Wanninkhof, R.: Relationship between Wind-Speed and GasExchange over the Ocean, J. Geophys. Res.-Oc., 97, 7373-7382, 1992.

Weiss, R. F.: Carbon dioxide in water and seawater: the solubility of a non-ideal gas, Mar. Chem., 2, 203-215, 1974.

Wood, P. E. and Petty, C. A.: New model for turbulent mass transfer near a rigid interface, AIChE Journal, 29, 164-167, doi:10.1002/aic.690290126, 1983.

Zeebe, R. E. and Wolf-Gladrow, D.: $\mathrm{CO}_{2}$ in Seawater: Equilibrium, Kinetics, Isotopes, no. 65 in Elsevier Oceanography Series, Elsevier, 1st Edn., 2001.

Zeebe, R. E., Zachos, J. C., Caldeira, K., and Tyrrell, T.: Oceans Carbon emissions and acidification, Science, 321, 51-52, 2008.

Zhang, J., Gilbert, D., Gooday, A. J., Levin, L., Naqvi, S. W. A., Middelburg, J. J., Scranton, M., Ekau, W., Pena, A., Dewitte, B., Oguz, T., Monteiro, P. M. S., Urban, E., Rabalais, N. N., Ittekkot, V., Kemp, W. M., Ulloa, O., Elmgren, R., Escobar-Briones, E., and Van der Plas, A. K.: Natural and human-induced hypoxia and consequences for coastal areas: synthesis and future development, Biogeosciences, 7, 1443-1467, doi:10.5194/bg-7-14432010, 2010. 